\title{
集 録
}

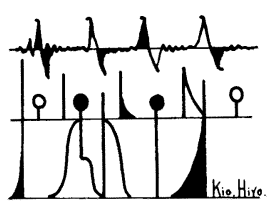

\section{圧力一温度状態図 (I) \\ (一成 分 系)}

\section{1. は じ め に}

高压物性学の研究の糜我は決して新しいものではな い.すでに, 1869 年には Amagat, 1870 年には Cailletet

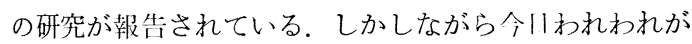
高压物性とよぶ研究は, Bridgmanによつて開始され, かつ発展させられたといつても過霖ではない，高压研究 に画期的な変草をもたらしたブリジマン型高压パッキ ング法の考案による流体高圧発生法にはじまり，ブリ ジン型アンビルとよばれる固体圧縮法などの開発など 数々の高正発生法の案出によつて精力的に行なわれた物 性研究に関する，この才面の彼の業績は偉大である。こ の時代に持ける研究手段としての高圧技術は特殊な実験 技術の一つと考えられ，ポピェラーな研究手段とはいえ なかつた. しかしながらここ十数年の高圧下の物性，金 属研究の文献を調べると，研究の進展の跡は日をみはら せるものがある. 現在, 物性, 金属学の分野に拈いて圧 カというパラメーターは温度とともに欠くことの出来な い重要な位置を占めているといつてよいくらいである。 金属学の分野では, 著しい间压技術の進步と多種多様な “高温”+“䯩压” の装置の考案により高压研究の報告 は年々增加の傾问にある。そういう中で単体金属のみな らず合金, 化合物に拈よぶ圧力 - 温度状態図の研究の発 展は, 注目すべき一つの研究分野となつている. 温度, 肚力などは, “物性の状態”について考察を加えるにあ たり欠くことの出来ない重要なパラメーターであるにも かかわらず, 従来, 合金系などの成分比 - 温度の平衡状 態図について詳細な研究があるが，洞体とくに金属の温 度一诗力状態阑の研究がほとんどなかつたのは, むしろ不 思議なこととされるべきで，この分野はいわば古くて新 しい課題といえよう。またこのような分野の発展の背景 は，単に技術手段の発展といつたものに寄せられるべき あのではない. 第一に材料学的立場からみるなら宇宙空
金子 武次郎* 三 浦 成 人* $^{*}$

間，原子力などの開発にともないきわめて高性能な材料 が要求されていることである.二つにはこれまでのよう な熱処理法や合金添加物の改良によつて達成され得なか つた高性能材料を高圧相物質に見出そうという指向が働 いている，高圧相の金属を常圧下に定着せしめて，新金 属材料の開発を進めるということには現在な打数々の困 難が存在することはもちろんであるが，ともかくも新材 料開発の一つの道が開かれつつあるということは確かで ある，第二に基礎的研究の面では，固体内原子間距離の 変化によつて起こる物性の変化が, 物体に対してわれわ れがもつている認識が，正しいものであるかどうか判断 する上できわめて重要な示唆を与える可能性の存在する ことである，とくに超高圧下でみられる絶縁体－金属転 移はあらためて“金属”とは何かという新鮮な話題を提 供しているものの一つである。その他にも金属の電子遷 移による転移や，圧力による融点の降下などは，金属物 性の研究にとつてきわめて興味あるテーマである。しか しながらこのような背景と膨大な研究成果にもかかわら ず材料の開発, 基礎的理論的研究という点では現在あま りいうべきほどの進展を見せていない，このへんが今後 の課題ともいえよう.

この稿は単体金属(固体)，合金，化合物の圧力 - 温度 状態図を集録することにあつたが，今回は単体のものに 限つた，限られた資料から作られたものであり，不完全 なものではあるが，圧力－温度状態図に関しては，この ような状態図集ともいうべきものは，いまのところ他に みあたらないこの集録の存在意義む，そんなところに あるかと思つている，最後の章に蛇足とも思われるが， 熱力学的なことを少々書き加えた．これはハンセンの状 態困などを直観的にみなれた人が，この種のものも同様 に直観的にみるのに役に立つのではないかと思つたから である。

\footnotetext{
* 東北大学金属材料研究所
} 


\section{2. 種々の物質の圧力-温度状態図}

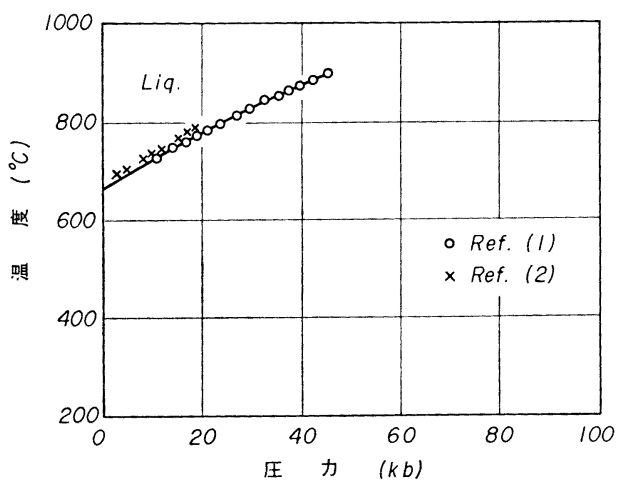

Al

(1) A.Jayaraman, W.Klement, Jr., R.C.Newton and G. C. Kennedy : J. Phys. Chem. Solids, 24 (1963) , 7.

(2) V.P.Butuzov : Sov.Phys. Cryst., 2 (1957) , 533.

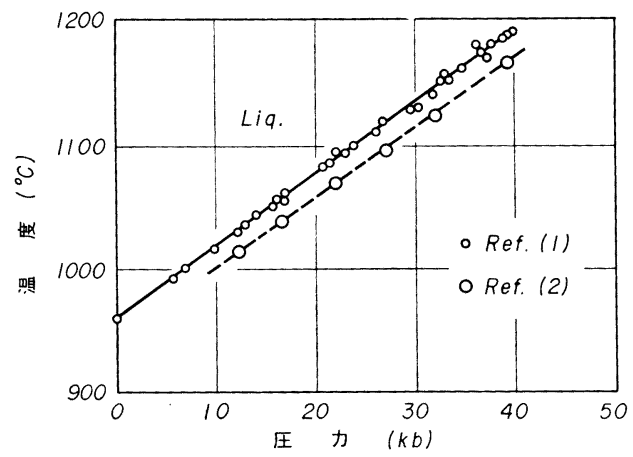

Ag

(1) L. H. Cohen, W. Klement, Jr. and G. C. Kennedy : Phys. Rev., 145 (1966) , 519.

(2) G.C. Kennedy and R.C.Newton : Solids under Pressure, McGraw-Hill, New York, (1963), p. 163.

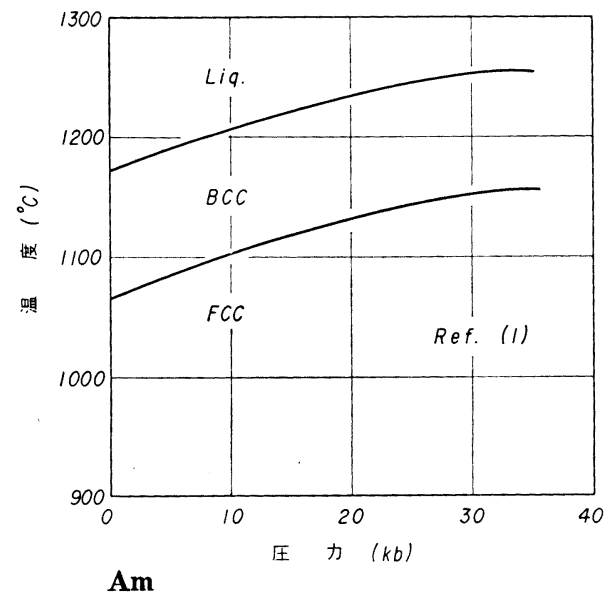

(1) D. R. Stephens, H. D. Stromberg and E. M. Lilley : J.Phys. Chem. Solids, 29 (1958), 815.

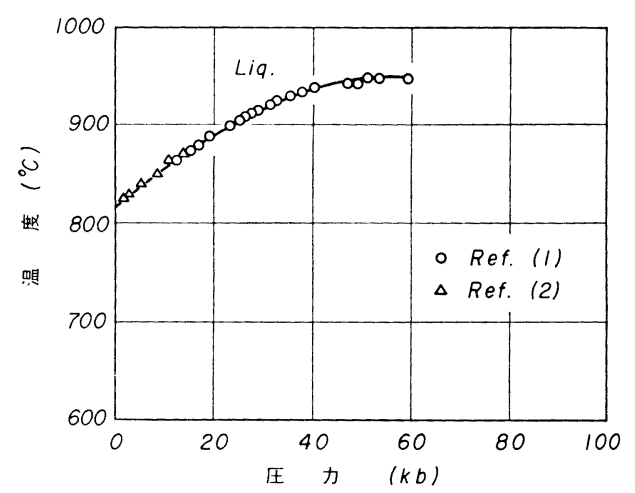

As

(1) W. Klement, Jr., A. Jayaraman and G. C. Kennedy : Phys. Rev., 131 (1963), 632.

(2) P.E.Chaney and S.E.Babb, Jr. : J.Chem.Phys., $43(1965), 1071$.

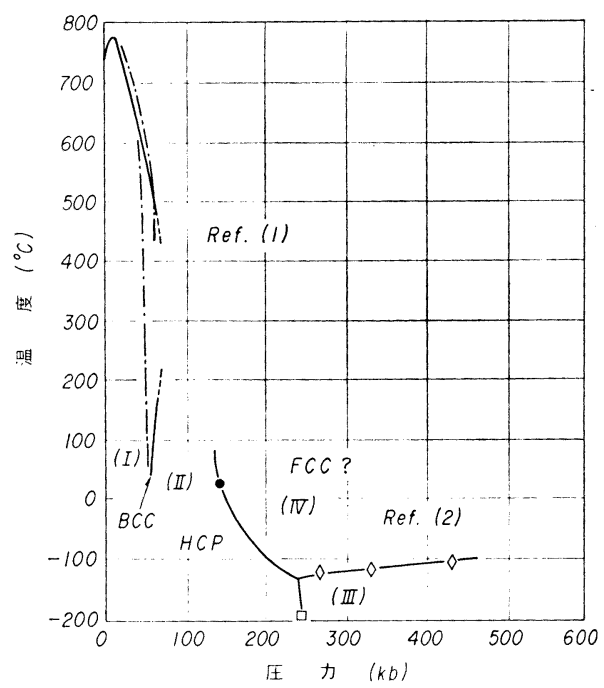

Ba

図は Susse et Epain(1), Drickamer ${ }^{(2)}$ による. Barnett et $\mathrm{al}^{(3)}$ によるX線回折によれば, Ba I $(B C C) a=5.025$, $\mathrm{BaII}(H C P) a=3.90, c / a=1.58(62 \mathrm{~kb})$ となる。電気抵 抗, 体積变化 ${ }^{(4)}$. Balchan, Drickamerによると Ba I $\rightarrow$ $\mathrm{Ba} I I(58 \mathrm{~kb})$, BaII $\rightarrow \mathrm{Ba} N(146 \mathrm{~kb})$ の両転移点で電気抵 抗は増加する. $146 \mathrm{~kb}$ 以上の压力ではゆるやかに減少 している.

(1) C.Susse et R.Epain : J.Chim. Phys. (France), $63(1966), 1580$.

(2) H.G.Drickamer : Solid State Physics, vol.17, ed. by F.Seitz and D.Turnbull.

(3) J.D. Barnett, R.B. Nennion and H.T.Hall: Science, 141 (1963), 534.

(4) E.P.Bundy and H.M.Strong : Solid State Physics, vol.13, ed. by F.Seitz and D.Turnbull.

(5) A.S.Balchan and H.G.Drickamer : Rev. Sci. Instr, 32 (1961), 308. 


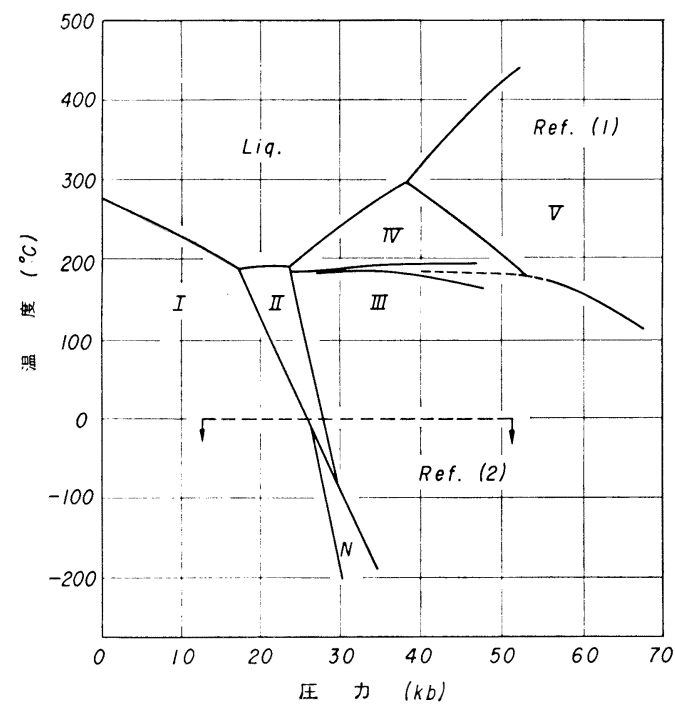

Bi 1

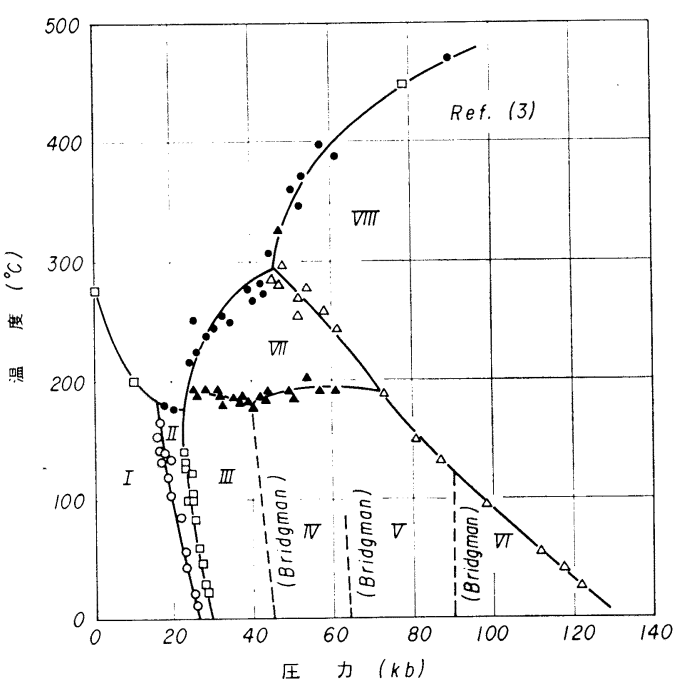

Bi 2

Bi

$\mathrm{Bi}$ の転移が圧力較正点として用いられていることか らしても，Bi の圧力-温度相図はよく調べられている. 図 Bi 1 には Klement, Jr., et al ${ }^{(1)}$ と最近低温の相図を調 べた Il'ina，Itskevich (2)によるものがのせてある。 各三 重点は I $\rightarrow$ II $\rightarrow$ Liq. $\left(16.7 \mathrm{~kb}, 191^{\circ} \mathrm{C}\right)$, I-N -Liq. (23.6 $\left.\mathrm{kb}, 191^{\circ} \mathrm{C}\right)$, II - III $-\mathrm{N}\left(24.0 \mathrm{~kb}, 180^{\circ} \mathrm{C}\right), \mathrm{N}-\mathrm{V}$-Liq. (38 $\left.\mathrm{kb}, 296^{\circ} \mathrm{C}\right), \mathrm{III}-\mathrm{N}-\mathrm{V}\left(52.6 \mathrm{~kb}, 174^{\circ} \mathrm{C}\right)$ である. 図 $\mathrm{Bi} 2$

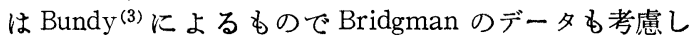
て第 8 相の存在まで予想している.

(1) W.Klement, Jr., A.Jayaraman and G.C.Kennedy: Phys. Rev., 131 (1963), 632.

(2) M.A.Il'ina and E.S.Itskevich : Sov. Phys. Solid State, 8(1967) , 1873.

(3) F.P. Bundy : Phys. Rev., 110 (1958), 314.

(4) G.C.Kennedy : Solids under Pressure, ed. by W. Paul and D.M. Warschauer (McGraw-Hill).

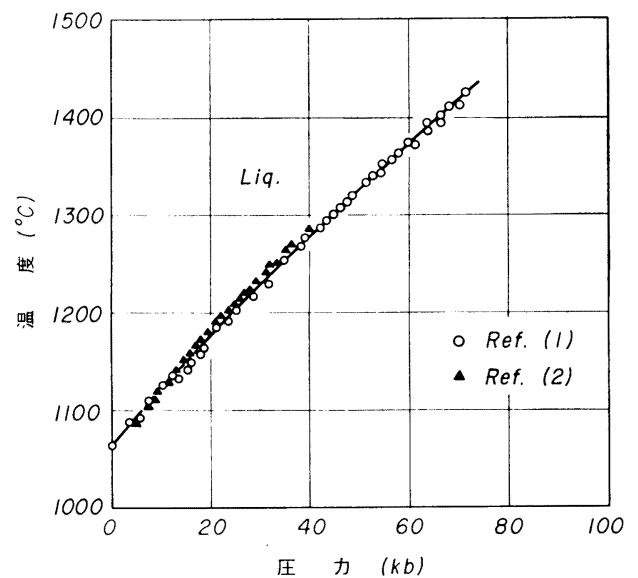

Au

(1) D. L. Decker and H. B. Vanfleet: Phys. Rev., 138 (1965) , A 129.

(2) L.H.Cohen, W. Klement, Jr. and G.C.Kennedy : Phys. Rev., 145 (1966), 519.

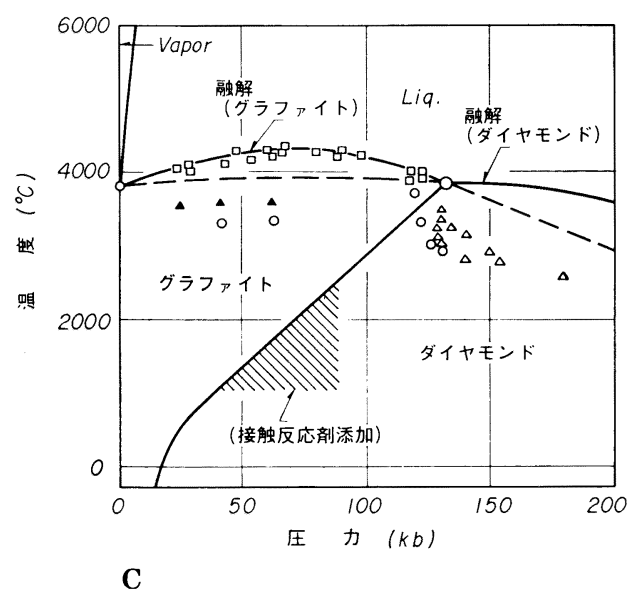

“接触区応剤添加”之書かれた斜線部分では触媒 (Group VIII Metals, or Cr, Mn, Ta, etc.) を使うことに より Graphite は diamond に移る. Graphite-diamondliquid 三重点は約 $130 \mathrm{~kb}$ ，約 $3800^{\circ} \mathrm{C}$ である. Graphite の melting curve は約 $4300^{\circ} \mathrm{C}, 60 \sim 70 \mathrm{~kb}$ に極大值をも

つ.な相中の記号はつぎのと掊り。
O No reaction
$\square$ Graphite melting
$\triangle$ Fast graphitization of diamond

$\Delta$ Fast conversion of graphite to diamond

(1) F.P.Bundy : Metallurgy at High Pressures and High Temperatures, Gordon and Breach Science Publishers, London, (1964), p.381. 


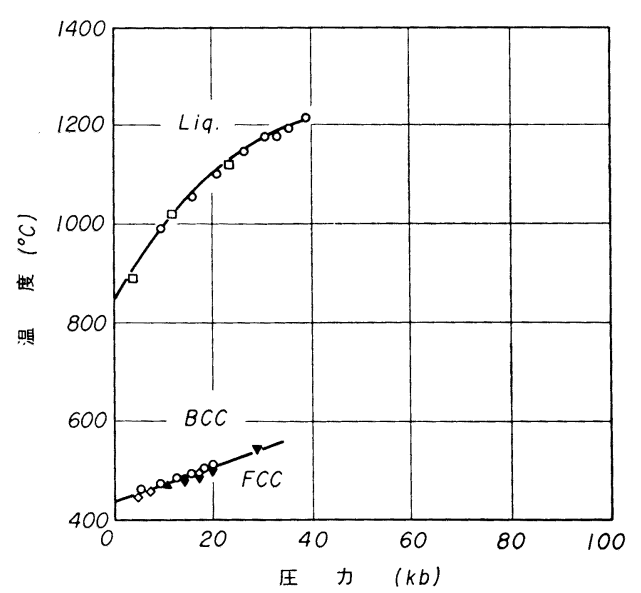

Ca

測定は DTA 法による.

(1) A.Jayaraman et al : Phys. Rev., 132(1963), 1620.

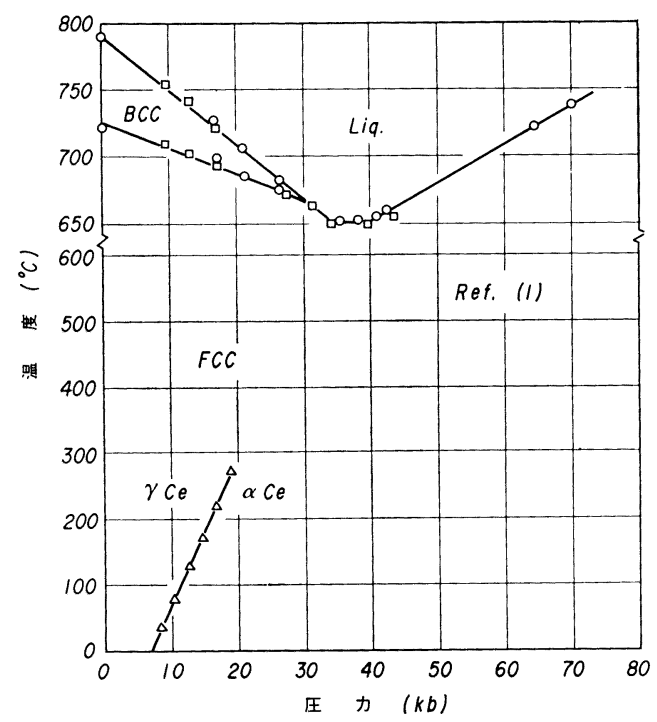

Ce

図は Jayaraman により DTA 法で調べられた相困で ある(1). FCC-BCC-Liq. の三重点は $T=674^{\circ} \mathrm{C}, p \approx 26$ $\mathrm{kb}$ である。 $\gamma \rightarrow \alpha \mathrm{Ce}$ 転移は結晶構造は変化せず，その 差異の起因は電子価状態の変化 $\left(4 f^{1}, 5 d^{1}, 6 s^{2} \leftrightarrows 4 f^{0}\right.$, $\left.5 d^{2}, 6 s^{2}\right)$ にるものとされている。 $\gamma \rightarrow \alpha \operatorname{Ce}$ の臨界点は Jayaraman $^{(1)}\left(\sim 277^{\circ} \mathrm{C}, 17.5 \mathrm{~kb}\right)$, Beecroft ${ }^{(2)}\left(357^{\circ} \mathrm{C}, 20\right.$ $\mathrm{kb})$, Ponyatovskii $\left(280^{\circ} \mathrm{C}, 18 \mathrm{~kb}\right)$ である. $F C C \rightarrow B C C$; $B C C \rightarrow$ Liq. 相境界の勾配が負であるのは，各相の密度 が $F C C<B C C<$ Liq. なることを示している.これは Liq. Ce の原子が $4 f \rightarrow 5 d$ 電子遷移のため小さくなつた ことによるものと思われる。 な特 X 線回折 ${ }^{(4)}$, 電気抵 抗 ${ }^{(5)}$ の測定もされている.

(1) A.Jayaraman : Phys. Rev., 137 (1965), A 179.

(2) R.I.Beecroft and C.A.Swenson : J.Phys. Chem. Solids, 15 (1960), 234.

(3) E.G.Ponyatovskii : Sov. Phys. Dokl., 3 (1958), 498.

(4) B.L.Davis and L.H.Adams : J.Phys. Chem. Solids, 25 (1964), 379.

(5) K.Gschneidner, Jr. et al : J.Phys.Chem. Solids $23(1962), 555$.

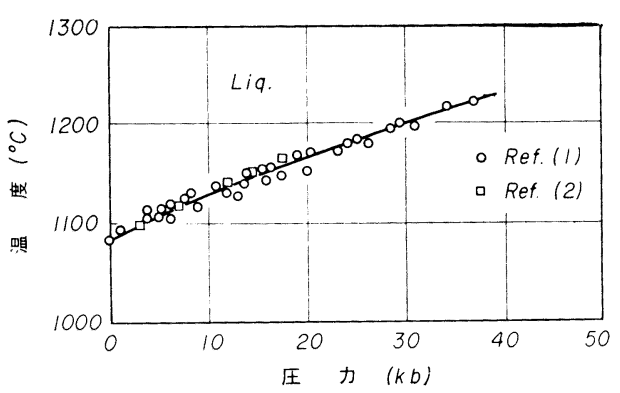

$\mathrm{Cu}$

(1) L.H.Cohen, W.Klement and G.C.Kennedy : Phys. Rev., 145 (1966), 519.

(2) M.Gonikberg, G.Shakhovskoi and V.Butuzov : Zh. Fiz. Khim, 31 (1957), 350.

\section{Dy}

希土類金属に関する高圧力下の研究報告の数はかなり 多い．本稿でも温度 - 压力状態四がはつきりしている金 属については記してあるが，磁気的転移による電気抵抗 も顕著なため, 結晶構造による転移と一見まぎらわし く, 確定しがたいものも多い. 以下いくつかの文献をあ げて拈くことだけにした。この中には磁気転移のみに関 するものあある(なお Pm, Dy, Ho, Er, Tm, Lu につい ては状態困はまだはつきりしていないようである)。

(1) R.A.Stoger and H.G.Drickamer : Phys. Rev., 133 (1964), A 830.

(2) A.Jayaraman : Phys. Rev., 139(1965), A 690.

(3) D.B.McWhan and A.L.Stevens : Phys. Rev., 139 (1965), A 682.

(4) J.E.Millon and T.A.Scott : Phys. Rev., 160 (1967), 387.

(5) A.Jayaraman and R.C.Shuwood: Phys. Rev., 134 (1964), 691 .

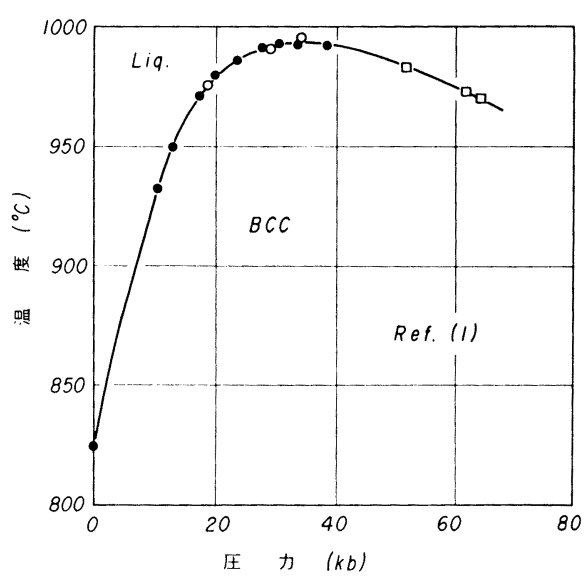

Eu

約 $40 \mathrm{~kb}$ をこえると融点が圧力によつて下がる.

(1) A.Jayaraman: Physics of Solid at High Pressure, ed. by C. T. Tomizuka and R. M. Emrich (Academic Press). 


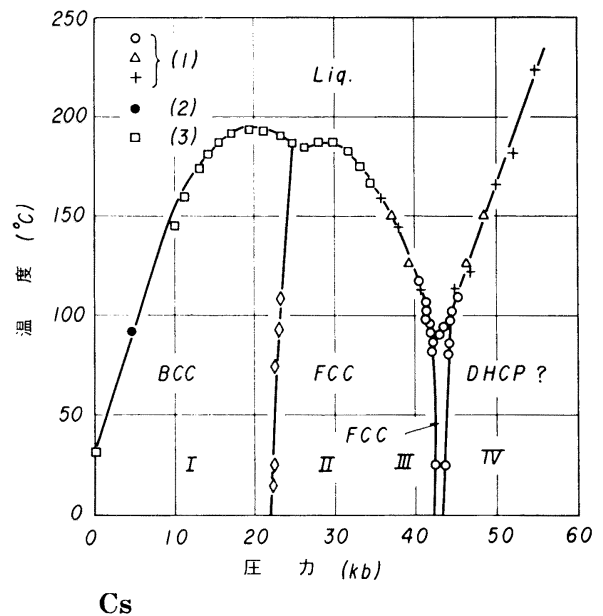

四はJayaraman et al (1), Kennedy et al (2) および Bridgman らの DTA や電氛抵抗変化で調べられたP-T 図である. Hall et al (4)による Cs I , Cs II , CsIII, CsIV の高 圧下X線回折によると, Cs I ( bcc $) a=6.067 \AA$ (at $78^{\circ} \mathrm{K}$ ), Cs II $(f c c) a=5.984 \pm 0.011 \AA$ (at $27^{\circ} \mathrm{C}$ and $41 \mathrm{~kb}$ ), Cs III $(f c c), a=5.800 \pm 0.007 \AA$ (at $27^{\circ} \mathrm{C}$ and $42.5 \mathrm{~kb}$ ), CsN (unknown)である. 電気抵抗の変化は Cs II $\rightarrow$ CsIII (増加) CsIII-CsI (減少)に際して急激で大きい. Cs I $\rightarrow$ CsII な どの転移は $6 s$ 電子の $3 d$ 状態への流孔込みによる電子 的転移であると考觉られている(5) (7). 三重点 Cs I-IIIL, CsIII-IV-L はそれぞれ $\left(88^{\circ} \mathrm{C}, 42.5 \mathrm{~kb}\right) ，\left(98^{\circ} \mathrm{C}, 43.9\right.$ kb)である.

(1) A.Jayaraman, R.C.Newton and J.M.McDonoughı : Phys. Rev., 159 (1967) , 527.

(2) G.C.Kennedy, A.Jayaraman and R.C. Newton: Phys. Rev., 126 (1962), 1363.

(3) P.W.Bridgman : Proc. Am. Acad. Arts, 81 (1952), 167.

(4) H.T.Hall, L.Merrill and J.D.Barnett : Science, 146 (1964), 1297.

(5) R.Steinheimer : Phys. Rev., 78 (1950), 235.

(6) E.S.Alekseev and R.G.Arkhipov: Sov. Phys. Solid State, 4(1962), 795.

(7) F.S.Ham : Phys. Rev., 128 (1962), 82.

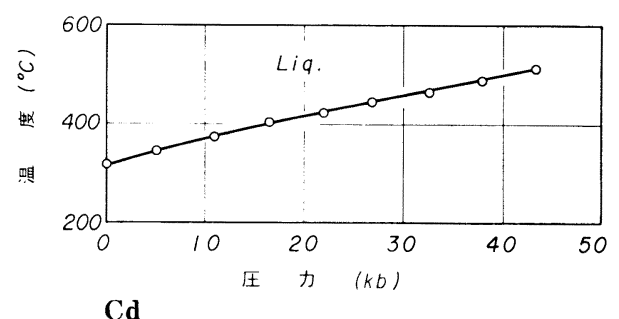

(1) G.C.Kennedy and R.C.Newton : Solids under Pressure, McGraw-Hill, New York, (1963), p. 163.

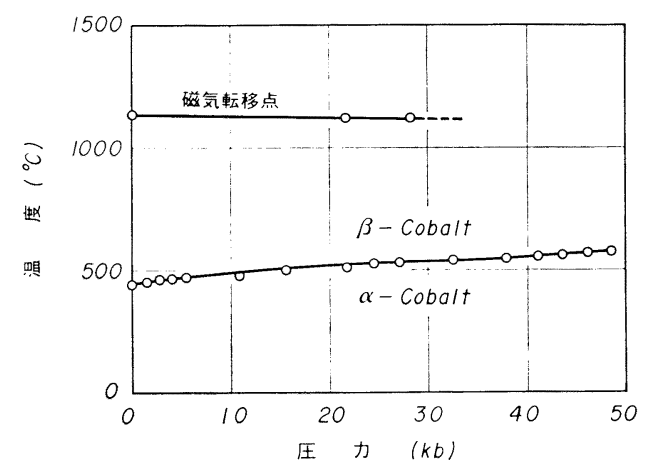

Co

$\alpha-\beta$ 転移は DTA 法で測定. Curie point の測定も DTA signal の变化により推定. Tc はほとんど圧力に依存し ない.

(1) G.C.Kennedy and R.C.Newton : Solids under Pressure, McGraw-Hill, New York, (1963), p. 163 .

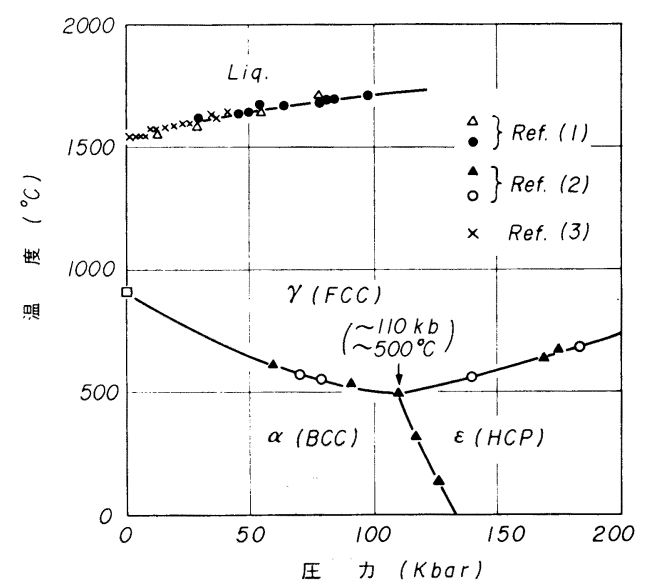

Fe

melting curve は電気抵抗変化による. $\alpha-\gamma-\varepsilon$ 三重点 は約 $110 \mathrm{~kb}, 500^{\circ} \mathrm{C}$ である. 図以外にも同様な相図が得 られている(4).

(1) H.M.Strong: Prog.Very High Pressure Research, Wiley, New York, (1961), 182.

(2) F.P.Bundy : J.Appl. Phys., 36 (1965) , 616.

(3) K.F.Sterretl et al : J.Geophys.Res., 70 (1965), 1979.

(4) S.A.Novikov, I. I. Divnov and A.G.Ivanov: Phys. Met. and Metallog., 21 (1966), No.2, 91.

\section{Er}

Dy の項参照, 文献 (2).

\section{Ho}

Dy の項参照, 文献 (2). 


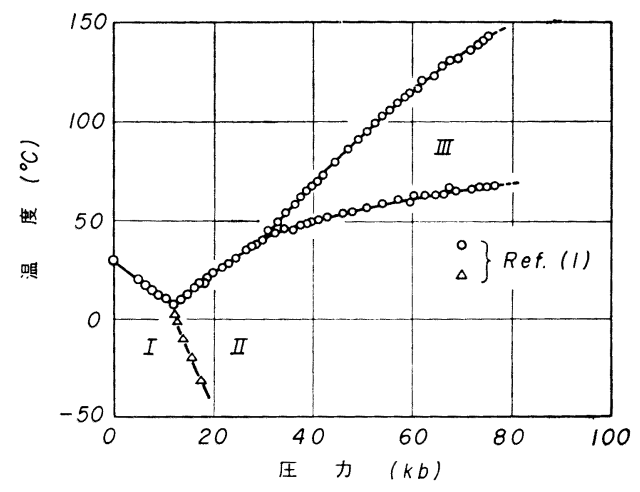

Ga

図中に拈いて， ○印は DTA 法, $\Delta$ 印は電気抵抗測定 による. 三重点は Liq.- I-II が $11.7 \mathrm{~kb}, 3^{\circ} \mathrm{C}$ であり, Liq.-IIIIII は $30.0 \mathrm{~kb}, 45^{\circ} \mathrm{C}$ である.

(1) A.Jayaraman, W. Klement, Jr., R.C. Newton and G.C.Kennedy : J.Phys. Chem. Solids, 24 (1963) , 7 .

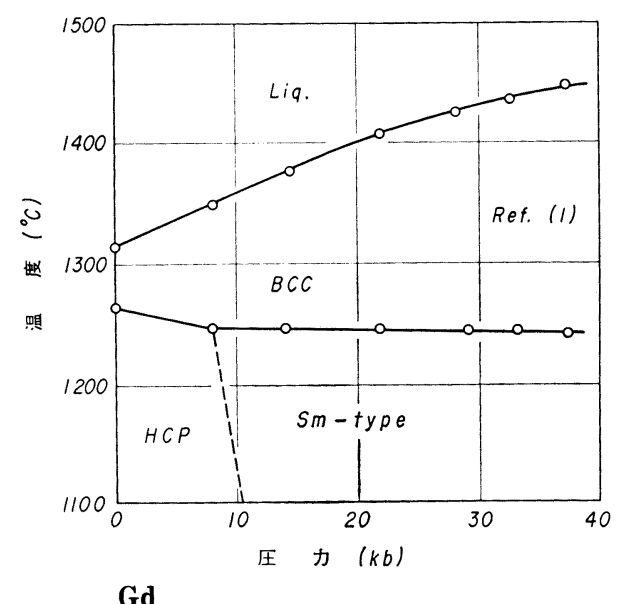

因は Jayaraman ${ }^{(1)}$ とょる高温高圧相図である。

Bridgman ${ }^{(2)}$ は室温 $25 \mathrm{~kb}$ で, 電気抵抗の異常を見出し ているが，これが室温に特ける $H C P \rightarrow$ Sm-type に対応 するものと思われる. Drickarmar ${ }^{(3)}$ は $200 \mathrm{~kb}$ 付近に電 気抵抗一圧力曲線の明らかな勾配の違いを見出してい る. X線回折による $H C P \rightarrow$ Sm-type 転移は McWhan, Stevens ${ }^{(4)}$ とよつて行なわれている.

(1) A.Jayaraman: Phys. Rev., 139 (1965) , A 690.

(2) P.W.Bridgman : Proc. Am. Acad. Arts. Sci., 82 (1953) , 95.

(3) H.G.Drickamar : Solid State Physics, vol. 19, ed.by F.Seitz and D. Turnbull.

(4) D.B.McWhan and A.L.Stevens : Phys. Rev., $139(1965)$, A 682.

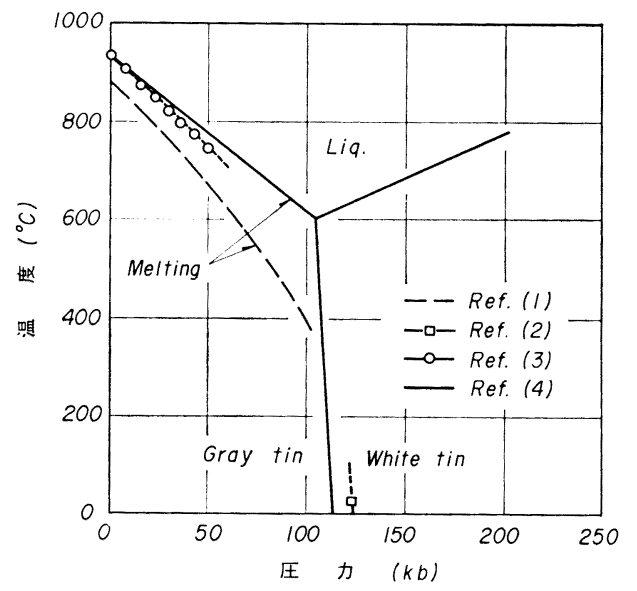

Ge

Liq.-Diamond-metallic の三重点は約 $103 \mathrm{~kb}, 600^{\circ} \mathrm{C}$ である(4).

(1) H.T.Hall : J.Phys. Chem., 59 (1955), 1144.

(2) S. Minomura and H. G. Drickamer : J. Phys. Chem. Solids, 23 (1962), 451.

(3) A. Jayaraman, W. Klement, Jr. and G.C. Kennedy : Phys. Rev., 130 (1963), 540.

(4) F.P.Bundy : J.Chem. Phys., 41 (1964), 3809.

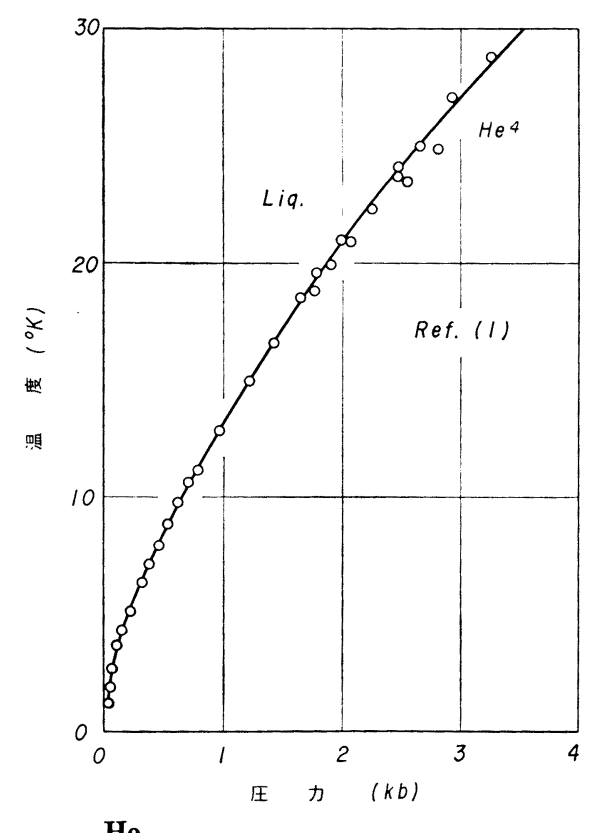

He の場合, 液体状態でもいくつかの相が存在する. その压力-温度曲線は文献 ${ }^{(2)}$ にある。

(1) R. L. Mills and E. G. Grilly : Phys. Rev., 99 (1955) , 480.

(2) C.A.Swenson : Solids under Pressure, ed. by W. Paul and D.M.Waschauer, McGraw-Hill Book, p. 41 . 


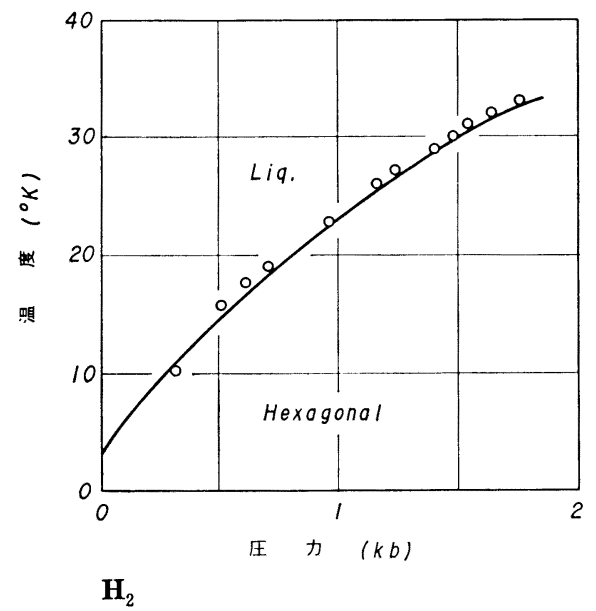

(1) R.L.Mills and E.R.Grilly : Phys. Rev., 99 (1955) , 480.

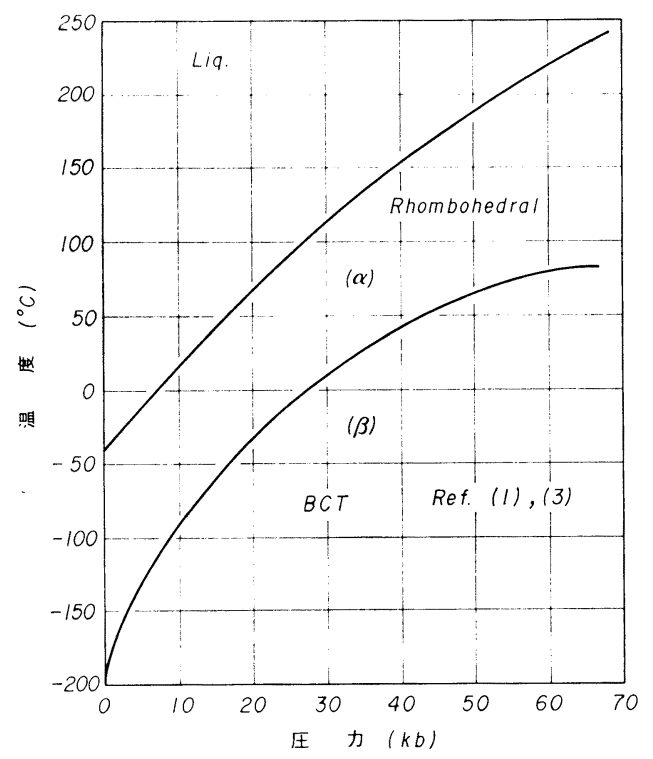

$\mathrm{Hg}$

X線回折が Barnett ${ }^{(4)(5)}$ とよつて行なわれている.

(1) W. Klement, Jr., A. Jayaraman and G. C. Kennedy : Phys. Rev., 131 (1963), 1.

(2) C.A.Swenson : Phys. Rev., 111 (1958), 82.

(3) F.P.Bundy and H.M. Strong: Solid State Physics, vol.13, ed. by F. Seitz and D.Turnbull.

(4) J.D.Barnett : Acta Cryst., 10 (1957), 58.

(5) M. Atoji, J. E. Shiber and C. A. Swenson : J. Chem. Phys., 31 (1959), 1628.

\section{Lu}

Dy の項参照, 文献 (2).

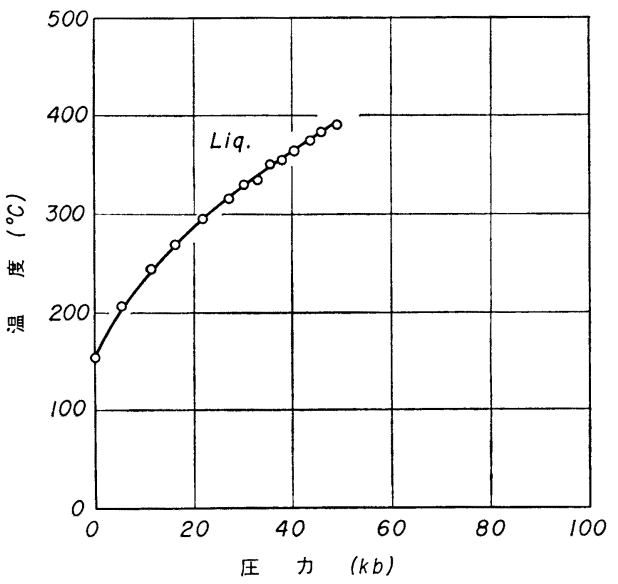

In

(1) G.C.Kennedy and R.C. Newton : Solids under Pressure, McGraw-Hill, New York, (1963), p. 163.

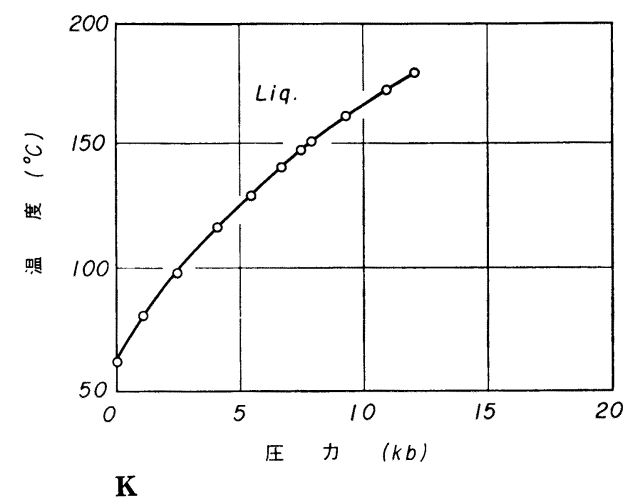

P.W.Bridgman : Phys. Rev., 3 (1914), 153.

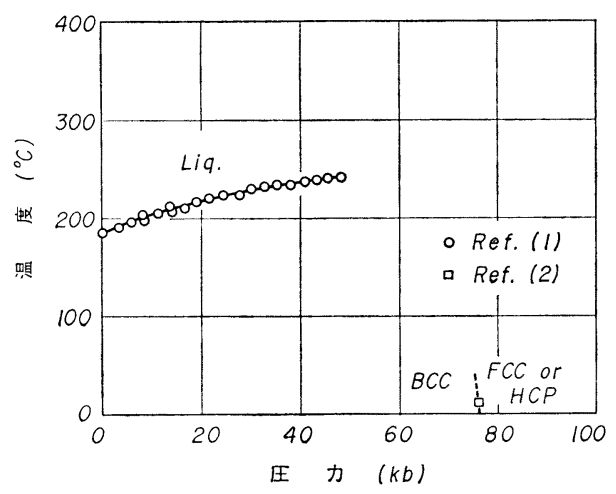

Li

$296^{\circ} \mathrm{K}$ に扔いて約 $80 \mathrm{~kb}$ 以上では metallic と考兄られ る(2).

(1) G.C.Kennedy and R.C.Newton : Solids under Pressure, McGraw-Hill, New York, (1963), p. 163.

(2) P.W.Bridgman : Proc. Am. Acad. Arts.Sci., 81 (1952) , 165. 


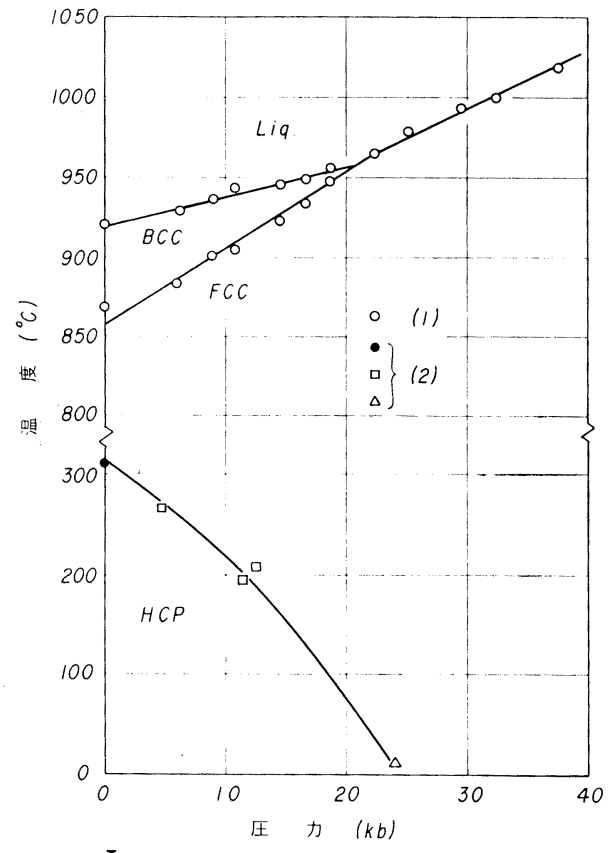

La

(1) A.Jayaraman : Phys. Rev., 139 (1965), A 690.

(2) D.McWhan, P.W.Montgomery, H.D.Stromberg and G.Jura : J.Phys. Chem., 67 (1963) , 2308.

(3) P.W.Bridgman : Proc.Am. Acad. Arts. Sci, 74 (1942), 425; 76 (1948), 55.

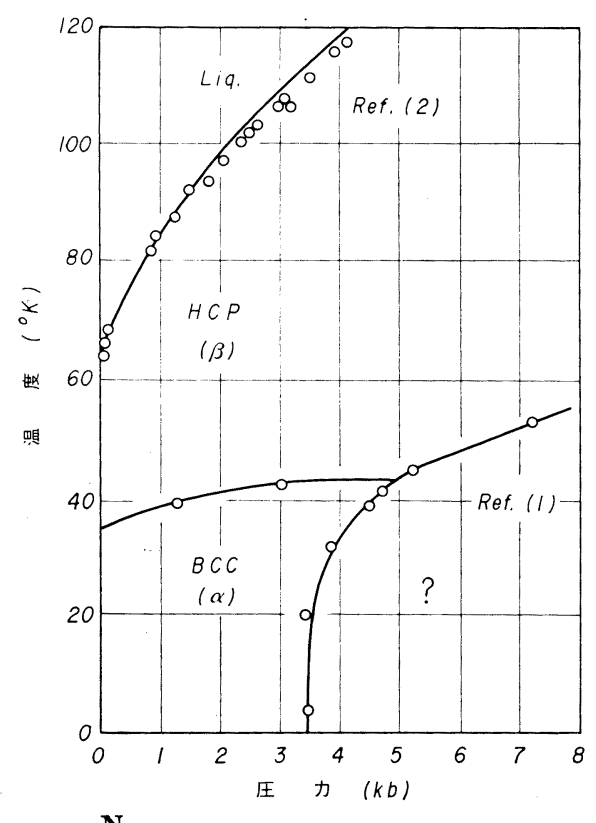

(1) C.A.Swenson : J.Chem. Phys., 23 (1955), 1963 ; Solids under Pressure, ed.by W.Paul and D.M. Waschareer, McGraw-Hill Book, p.41.

(2) R. L. Mills and E. R. Grilly : Phys. Rev., 99 (1955), 480 .

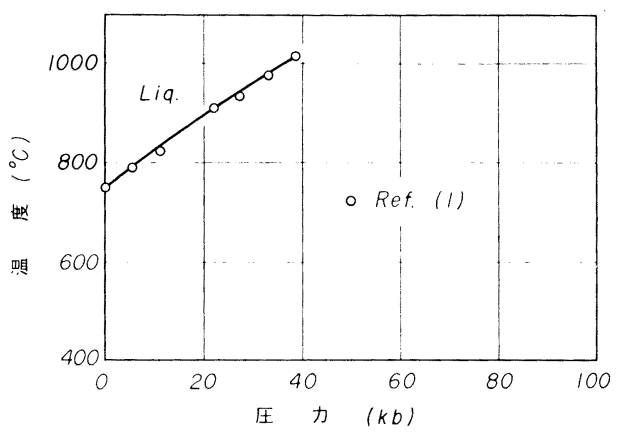

Mg

(1) G. C. Kennedy and R. C. Newton : Solids under Pressure, McGraw-Hill, New York, (1963), p.163.

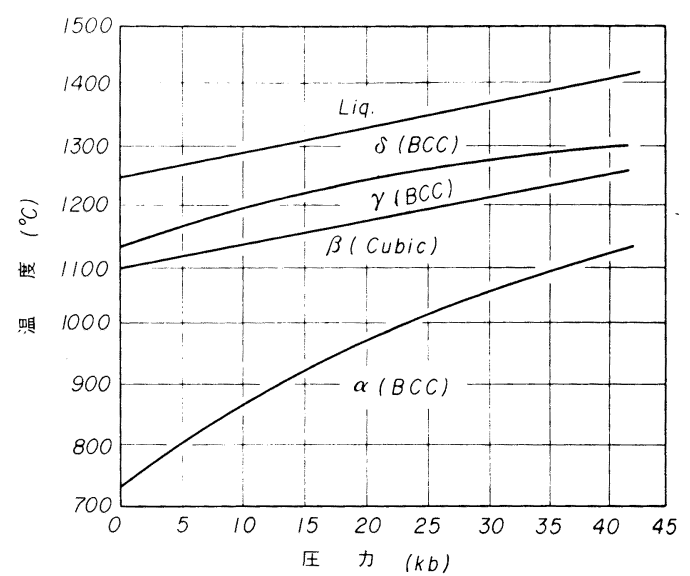

Mn

DTA 法による測定. $\alpha-\beta$ 転移曲線には加圧と減生と で hysteresis が見られる. 各転移曲線は $T=a+b p+c p^{2}$ で表わされるが, melting curve は $c=0$ であるような変 化を示す.

(1) E. Rapoport and G.C.Kennedy : J.Phys.Chem. Solids, 27 (1966), 93.

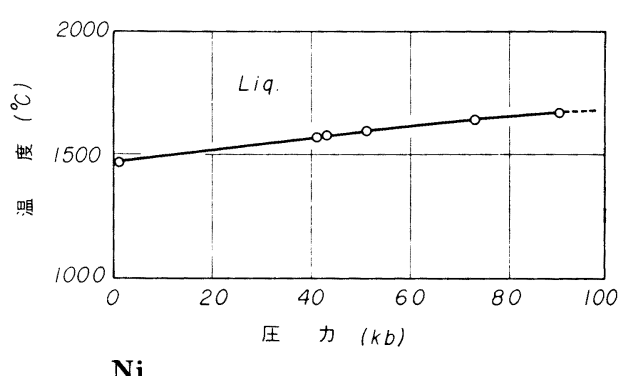

(1) H.M.Strong and F.P.Bundy : Phys. Rev., 115 (1959), 278. 


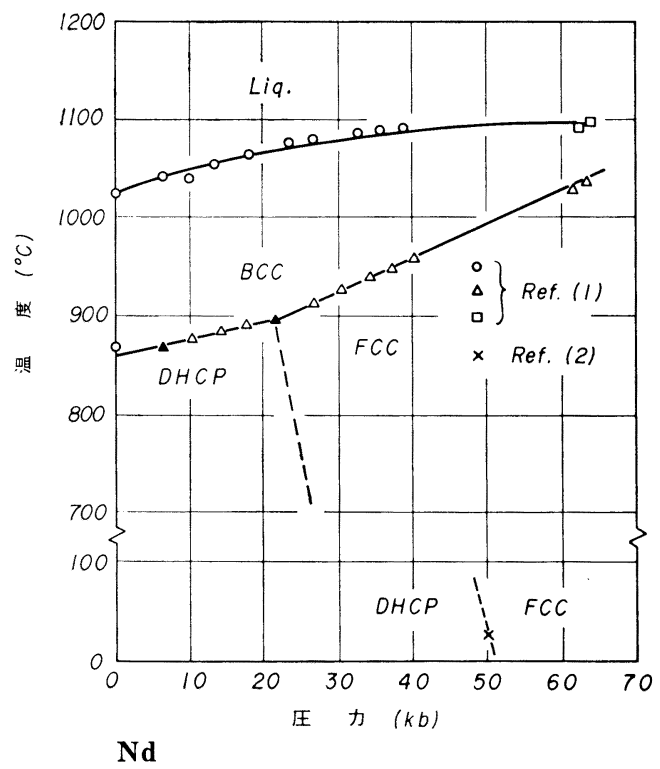

汹は Jayaraman (1)による㥵为である。Piermarini と Weir ${ }^{(2)}$ は〜 $50 \mathrm{~kb}$ の压汃下X線回折で FCC 相への転移を 確かめた. $600 \mathrm{~kb}$ までの電気抵抗の測定が Drickamer ${ }^{(3)}$ により行なわれている. $296^{\circ} \mathrm{K}: 120 \mathrm{~kb}(\mathrm{~min}), 200 \mathrm{~kb}$ (broad $\max$ ), $197^{\circ} \mathrm{K}: 100 \sim 110 \mathrm{~kb}(\max ), 135 \mathrm{~kb}(\min )$, $77^{\circ} \mathrm{K}: 170 \sim 175 \mathrm{~kb}$ (sharp $\left.\max \right)$.

(1) A.Jayaraman : Phys. Rev., 139(1965), A 690.

(2) G.J. Piermarini and C.E. Weir : Science, 144 (1964), 69.

(3) H.G.Drickamar : Solid State Physics, vol.17, ed. by F.Seitz and D.Turnbull.

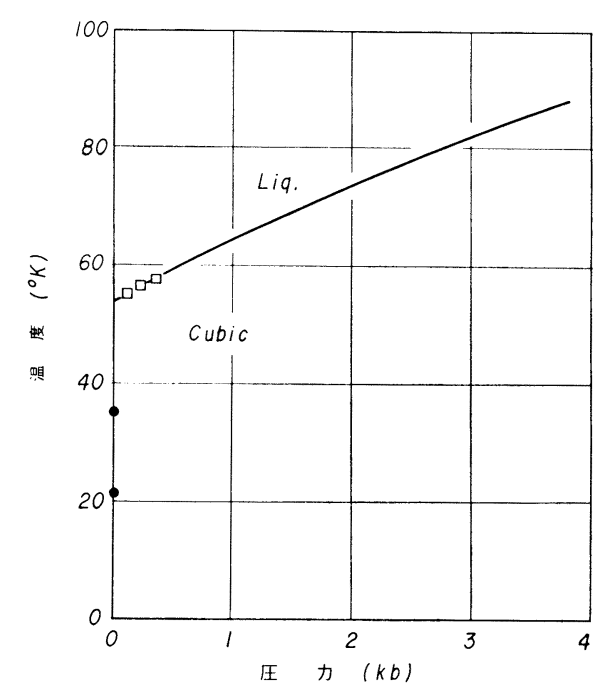

O

(1) R.L.Mills and E.R. Grilly : Phys. Rev., 99 (1955), 480 .

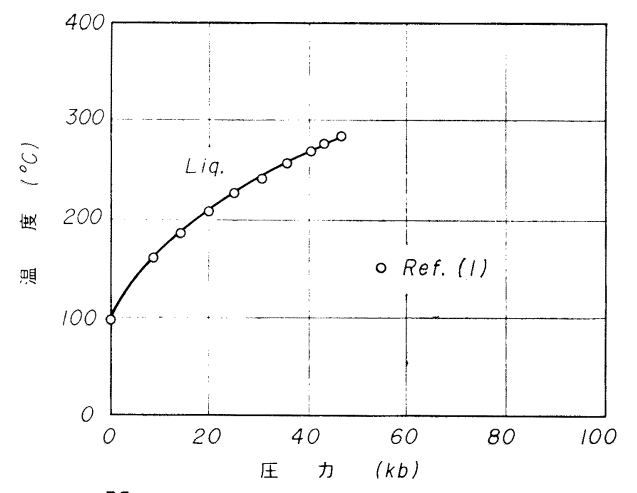

$\mathrm{Na}$

(1) G.C.Kennedy and R.C. Newton : Solids under Pressure, McGraw-Hill, New York, (1963), p. 163 .

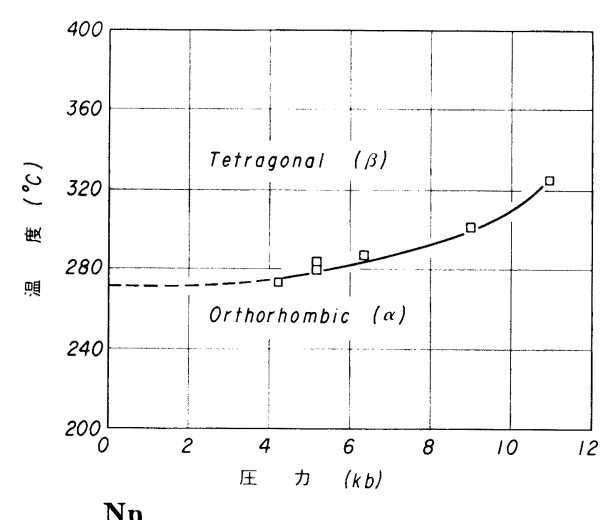

電気抵抗の変化によつて相変化を娭出している.

(1) D.McWhan, P.W.Montgomery, H.D.Stromberg and G. Jura : J.Phys. Chem., 67 (1963), 2308.

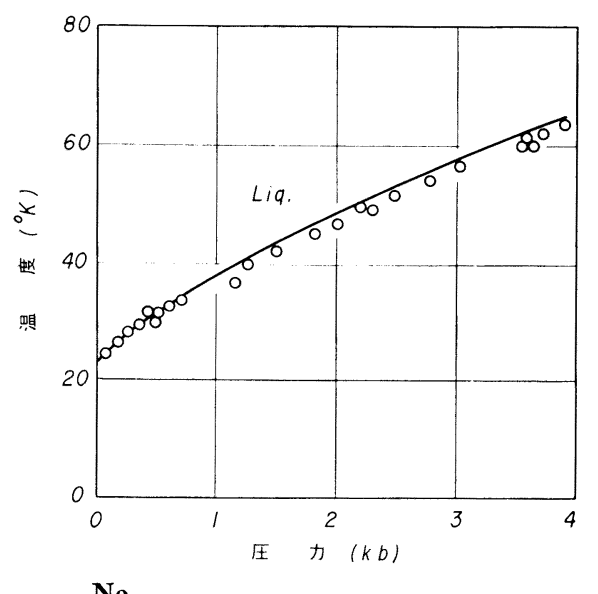

(1) R.L.Mills and E.G. Grilly : Phys. Rev., 99 (1955) , 480. 


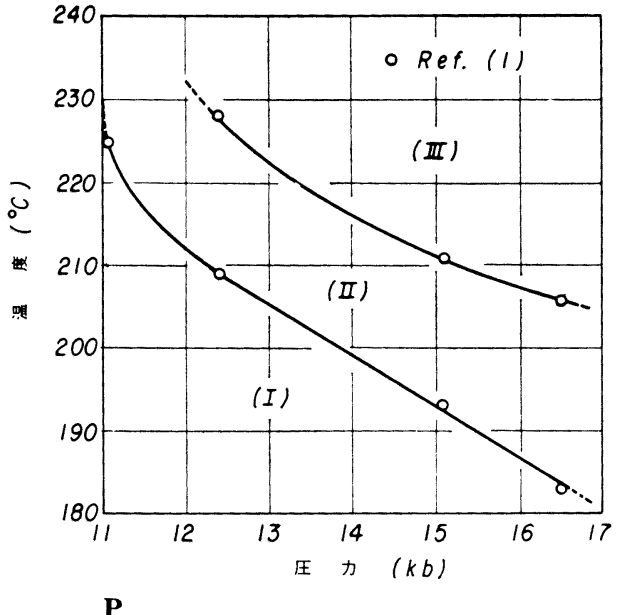

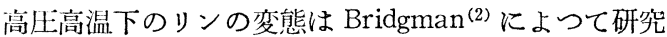
されたが，図はJacobs によるものである。困の(III)の 領域では白リンはただちに黒リンの結晶に変わる。（II） の領域では時間とともに結晶黑リンが生ずるが，（I）の 領域では非晶質等リンのみしか出来ない(1). 図示されて いないが, 室温, 約 $60 \mathrm{~kb}$ で赤リン $\rightarrow$ 黑リン変態に伴 5 とみられる電気抵抗の急激な減少が圧の上昇に伴い観測 されている(3).

(1) R.B.Jacobs: J.Chem. Phys., 5(1937), 945.

(2) P.W.Bridgman : J.Amer.Chem. Soc., 36 (1914), $1344 ; 38$ (1916), 609.

(3) R.E.Harris, R.J. Vaisnys, H. Stromberg and G.Jura : Progress in Very High Pressure Research, John Wiley and Sons. Inc., New York, (1961), p. 165 .

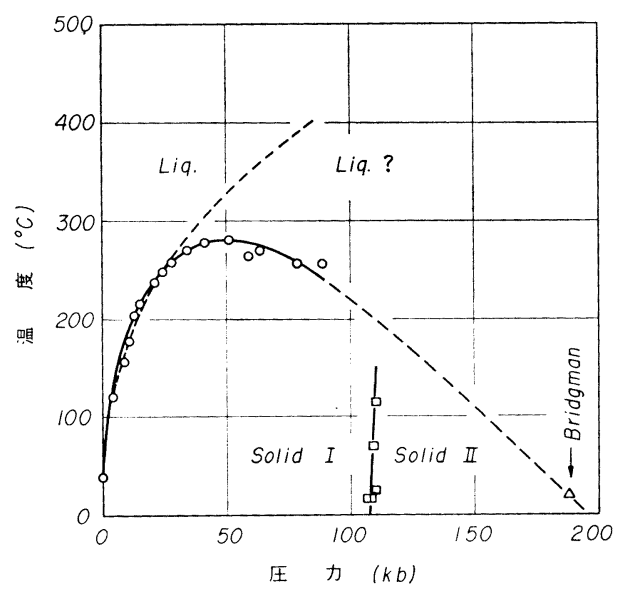

Rb

以訃の㷛線は、算值.

(1) F.P.Bundy : Phys. Rev., 115 (1959), 274.

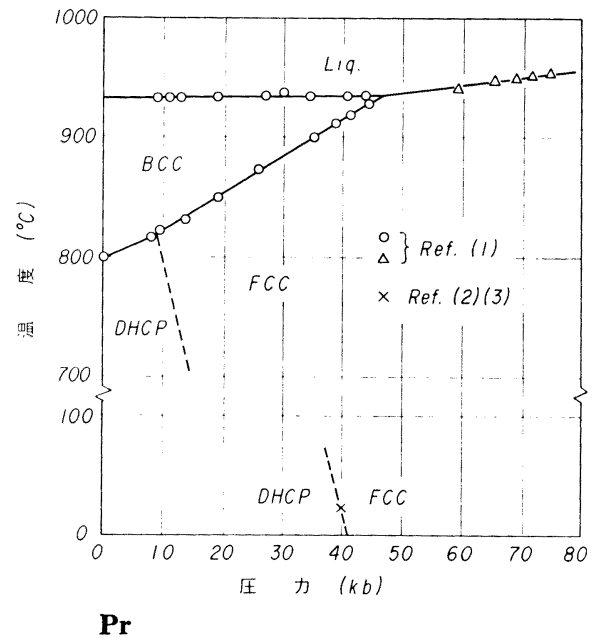

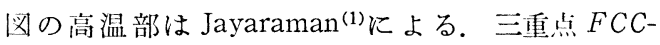
$B C C$-Liq. は $48 \mathrm{~kb}, 938^{\circ} \mathrm{C}, D H C P-F C C-B C C$ は $~ 8$ $\mathrm{kb}, \sim 810^{\circ} \mathrm{C}$ である。 室温にて Bridgman ${ }^{(2)}$ は $39 \mathrm{~kb}$ に 抵抗にとんがりを見出した。 Piermarini，Weir ${ }^{(3)}$ はX線 问折にて，40kb 下の相が FCC なることを確認した。

(1) A.Jayaraman : Phys.Rev., 139(1965), A 690.

(2) P.W.Bridgman : Proc. Am. Acad. Arts. Sci., 81 (1952), 165.

(3) G.J.Piermarini and C.E. Weir : Science, 144 (1964), 69 .

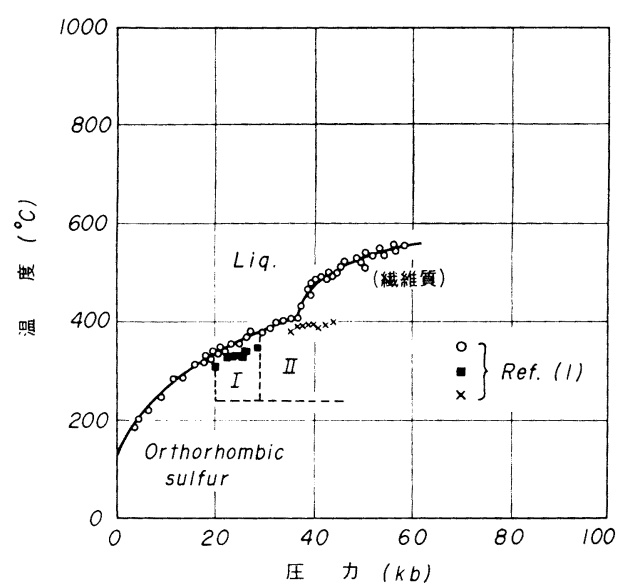

$\mathbf{S}$

melting curve および solid-solid transition は DTA 法 で測定. StructureはX線で決定した。 Triple pointは $37 \mathrm{~kb}, 410^{\circ} \mathrm{C}$ である。試料を一度溶かし, つぎに融点直 下で焼鈍 (15〜90分) したものは Triple point が $27 \mathrm{~kb}$, $380^{\circ} \mathrm{C}$ に下がる.このような試料は Fibrous Sulfur の混 入が少ない，完全な Orthorhombic Sulfur を高圧下で作 ることは㑣難であることから，異の Triple point はも5 少々下の爪力と混度を㭙すると考えられる(1).

(1) K.B.Ward, Jr. and B.C.Deaton : Phys.Rev., 153 (1967), 947. 


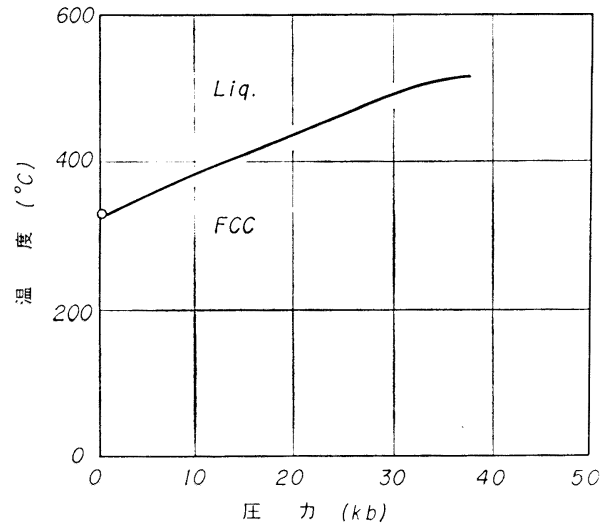

$\mathbf{P b}$

(1) E.P.Bundy and H.M.Strong: Solid State Physics, vol.13, ed. by F.Seitz and D.Turnbull.

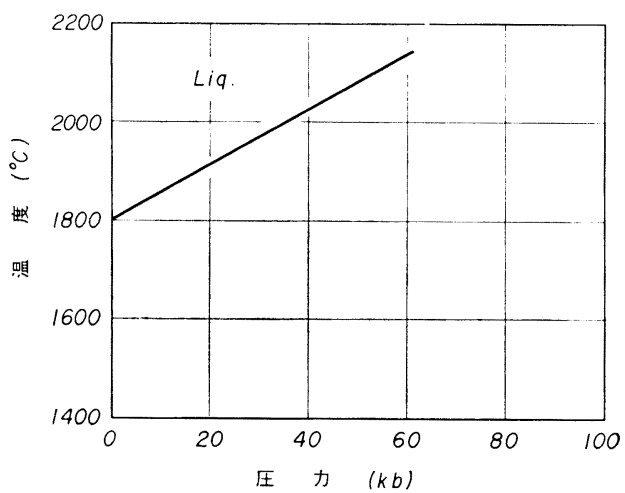

Rh

(1) M.S.Strong and F.P. Bundy : Phys. Rev., 115 (1959), 278.

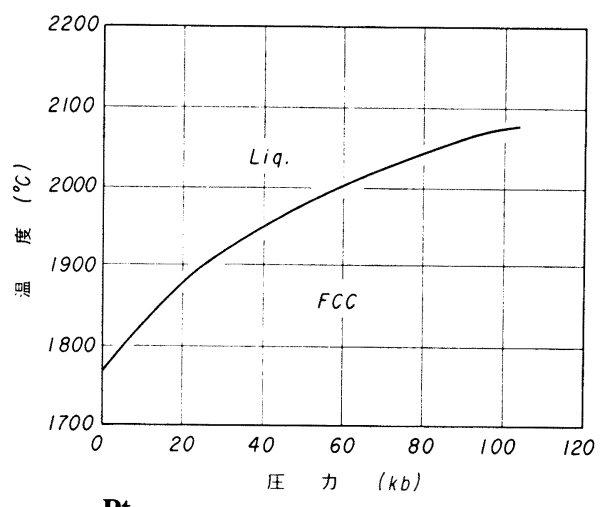

(1) H.M.Strong and F.P.Bundy : Phys. Rev., 115 (1959), 278.

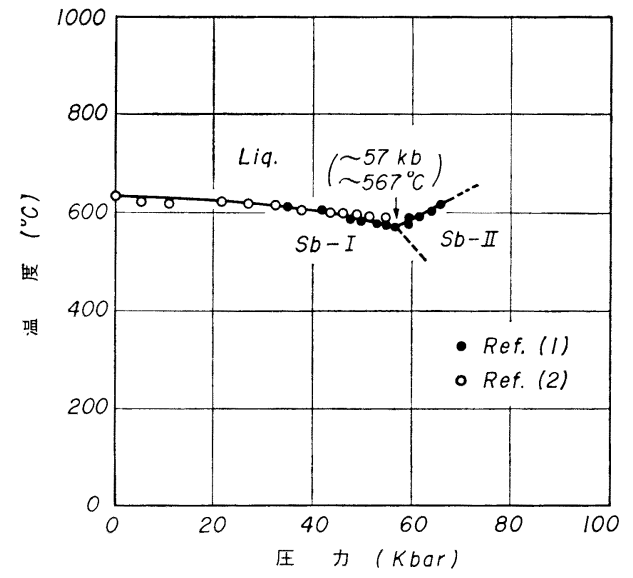

$\mathrm{Sb}$

三重点は $57 \mathrm{~kb}, 567^{\circ} \mathrm{C}^{(1)}$. Bridgman ${ }^{(3)}$ は室温で約 82 $\mathrm{kb}$ で電気抵抗の相転移によるとみられる急変を見出し ている.

(1) W. Klement, Jr., A. Jayaraman and G.C. Kennedy : Phys. Rev., 131 (1963), 632.

(2) G.C.Newton and R.C.Kennedy : Solids under Pressure, McGraw-Hill, New York, (1963), p. 163.

(3) P.W. Bridgman : Proc. Am. Acad. Arts. Sci., 72 (1938), 157 ; 81 (1952) , 169.

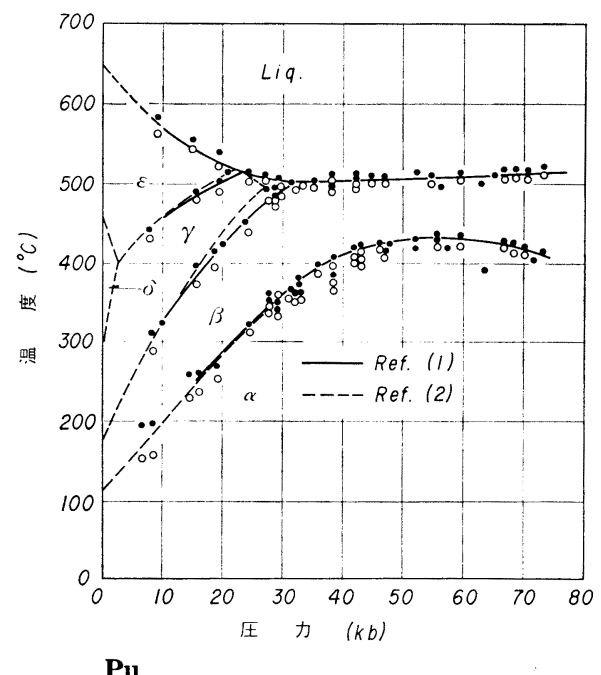

図は Liptai, Friddle ${ }^{(1)}$, Stevens ${ }^{(2)}$ の状態図である. 三つの三重点, $\delta-\gamma-\varepsilon, \gamma$ - $\varepsilon$-Liq. $\beta-\gamma$-Liq. があらわれる. $\alpha \rightleftarrows \beta$ の転移線が圧力が上がると，勾配をかえている。 約 $50 \mathrm{~kb}$ 以上で勾配は負となり， $\beta$ の方がより密なるの となつている. McWhan et $\mathrm{al}^{(4)}$ も電気抵抗の变化を 17 $\mathrm{kb}$ まで調べ，同じような $\alpha-\beta$ 線を得ている.

(1) R.G.Liptai and R.J.Friddle : J.Less-Common Metals, 10 (1966), 292.

(2) D.R.Stevens: J.Phys. Chem. Solids, 24 (1963), 1197.

(3) R.G.Liptai and R.J.Friddle : J.Nuc. Mat., 24 (1967), 316.

(4) D.McWhan, P. W. Montgomery, H.D.Stromberg and G.Jura: J.Phys. Chem., 67 (1963), 2308. 


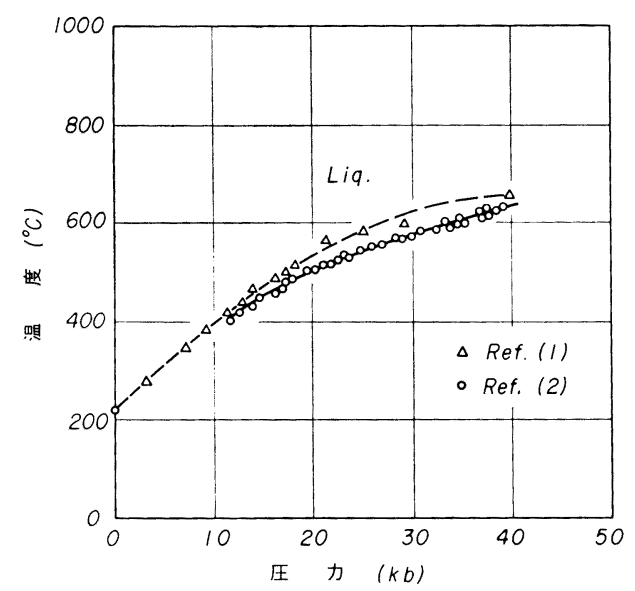

Se

(1) B.C.Deaton and F.A.Blum : Phys. Rev., 137 (1965), A 1131.

(2) W.Klement, Jr., L.H.Cohen and G.C.Kennedy : J.Phys. Chem. Solids, 27 (1966), 171.

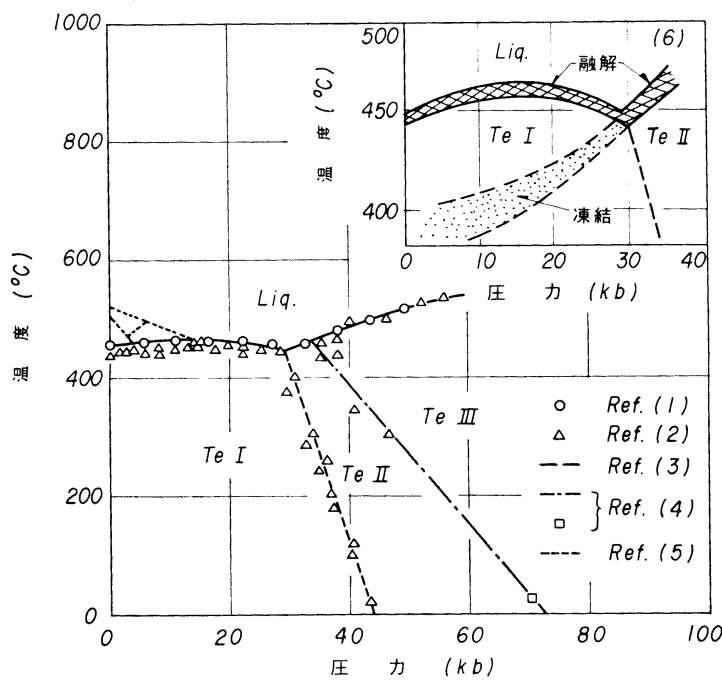

Te

TeI は約 $460^{\circ} \mathrm{C}, 15 \mathrm{~kb}$ で融点が極大となる. Liq.-

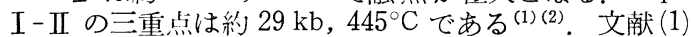
はDTA，(2)はDTA と電気抵抗，(3)，(4) は電気抵抗に よる測定. TeII は metallic phase である(2). TeIは 過冷却現象を高圧下でも示す ${ }^{(6)}$. Liq.Te で電気抵抗 は一様でなく, semiconducting-metallic 転移が見られ $た^{(6)}$.

(1) G.C.Kennedy and R. C. Newton : Solids under Pressure, McGraw-Hill, New York, (1963), p.163.

(2) F.A.Blum, Jr. and B.C.Deaton : Phys. Rev., 137 (1965) , A 1410.

(3) P.W.Bridgmann : Phys.Rev., 48(1935), 893.

(4) P.W.Bridgmann : Proc.Am. Acad. Arts.Sci., 74 (1939), 21.

(5) S.M.Stishov : J.Expt1.Theoret.Phys., 52 (1967), 1196.

(6) W.Klement, Jr., L.H.Cohen and G.C.Kennedy: J.Phys.Chem.Solids, 27 (1966), 171.

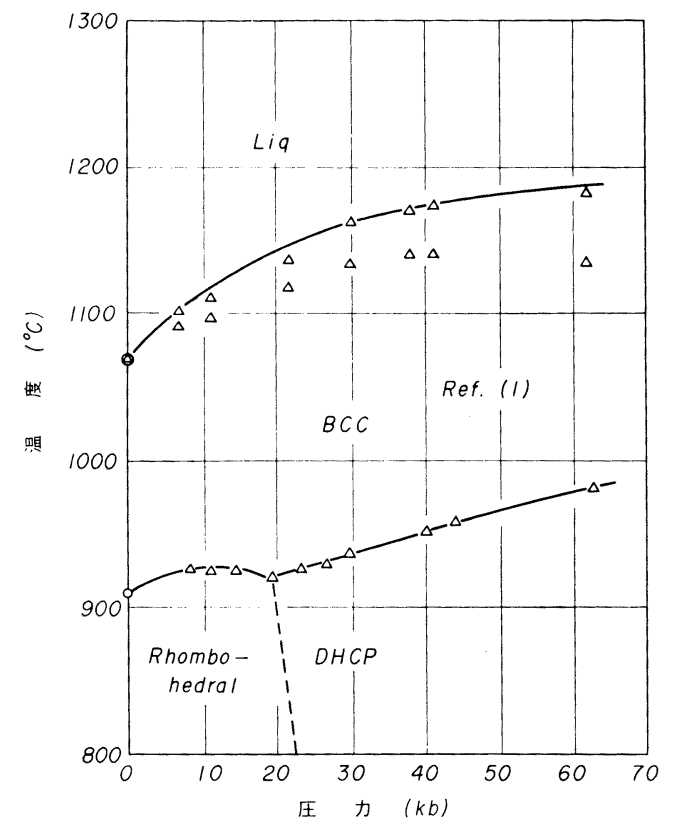

Sm

(1) A.Jayaraman : Phys. Rev., 139 (1965) , A 690.

(2) H. G. Drickamer : Solid State Physics, vol.17, ed. by F. Seitz and D.Turnbull.

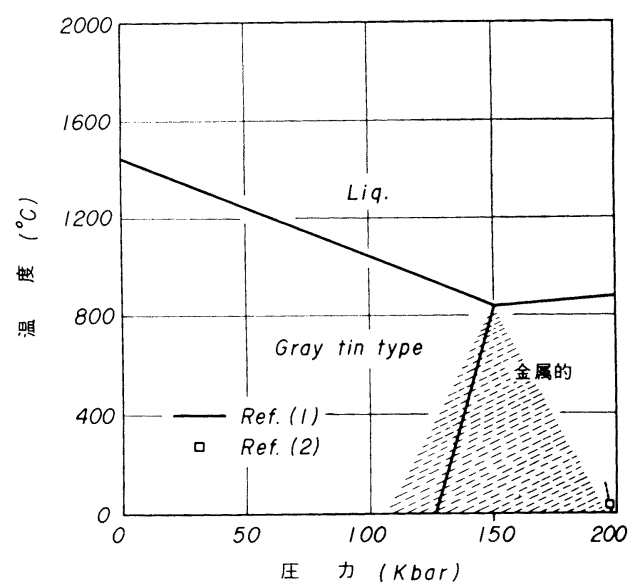

$\mathrm{Si}$

圧の上昇に伴 5 metallic への転移は徐々に行なわれ る (斜線部分) ${ }^{(1)}$ ．室温にて約 $200 \mathrm{~kb}$ で電気抵抗は压の 上昇飞伴い急激に減少する。この压以下では Gray tin type structure，それ以上では White tin type structure と報告されている(2).

(1) F.P.Bundy : J.Chem. Phys., 41 (1964) , 3809.

(2) S. Minomura and H.G. Drickamer : J.Phys. Chem. Solids, 23 (1963) , 451.

Tm

Dy の项参照, 文献 (2). 


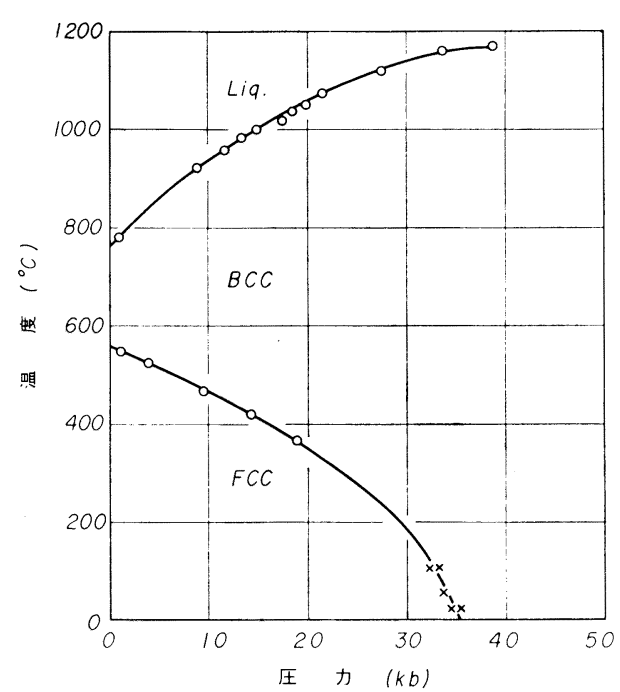

Sr

図中の○印は DTA 法， ×は電気抵抗と体積変化によ る測定.

(1) A. Jayaraman et al. : Phys. Rev., 132 (1963), 1620 .

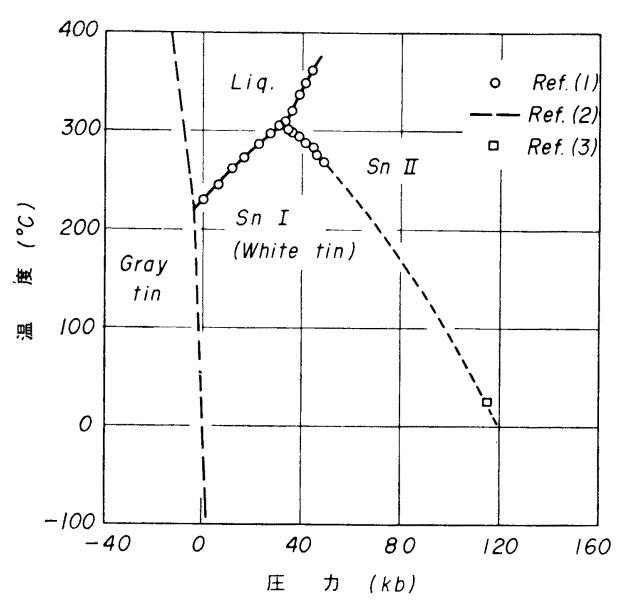

Sn

Liq. - I - II の三重点は $33 \mathrm{~kb}, 305^{\circ} \mathrm{C}$ である(1)。㕳中 の鎖線は熱力学的計算によつて求めた Gray Tin 相であ る(2). Liq.-Gray Tin-Sn I の三魚は $-4 \mathrm{~kb}, 220^{\circ} \mathrm{C} て ゙$ ある(2)

(1) G.C.Kennedy and R.C.Newton : Solids under Pressure, McGraw-Hill, New York, (1963), p.163.

(2) A. Jayaraman, W. Klement, Jr. and G. C. Kennedy : Phys. Rev., 130 (1963), 540.

(3) R.A.Stager, A.S.Balchen and H.G.Drickamer: J.Chem. Phys., 37 (1962), 1154.

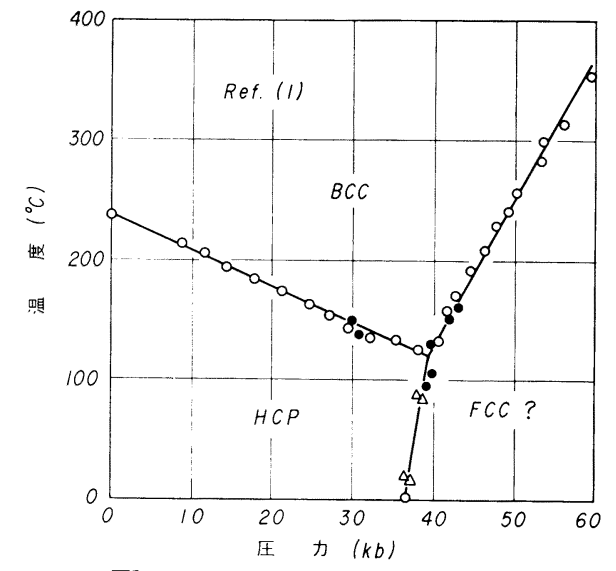

Tl

図は Jayaraman'(1)によるものである. Bridgman (1935) も $50 \mathrm{~kb}$ までの P-T 図を作つているが，HCPと $F C C$ 相間の境界線が $\partial T c / \partial p<0$ で Jayaraman と逆セ ンスになつている. Ponyatovskii(1958) による相図では FCC 相がみつけられていない.

(1) A.Jayaraman et al. : J.Phys. Chem. Solids, 24 (1963) , 7 .

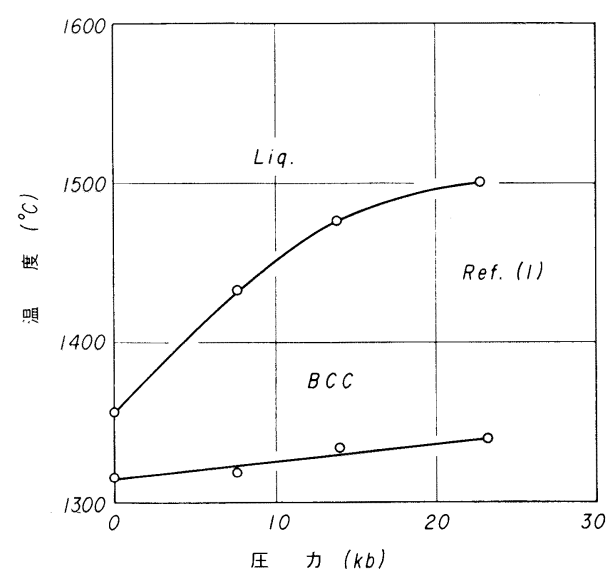

$\mathbf{T b}$

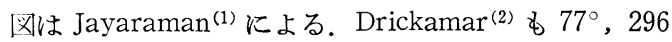
${ }^{\circ} \mathrm{K}$ にて $600 \mathrm{~kb}$ までの電気抵抗の测定を行なつている. 電気抵抗一圧力曲線に形の上で異常が認められているが, 明らかに第 1 次転移に相灿するものはない. Stomberg ${ }^{(3)}$ も $27 \mathrm{~kb}$ に電気抵抗の異常をみている.

(1) A.Jayaraman : Phys. Rev., 139 (1965), A 690.

(2) H. G. Drickamar : Solid State Physics, vol.17, ed. by F.Seitz and D.Turbull.

(3) H. D. Stomberg and D. R. Stephens - J.Phys. Chem. Solids, 25 (1964), 1015. 


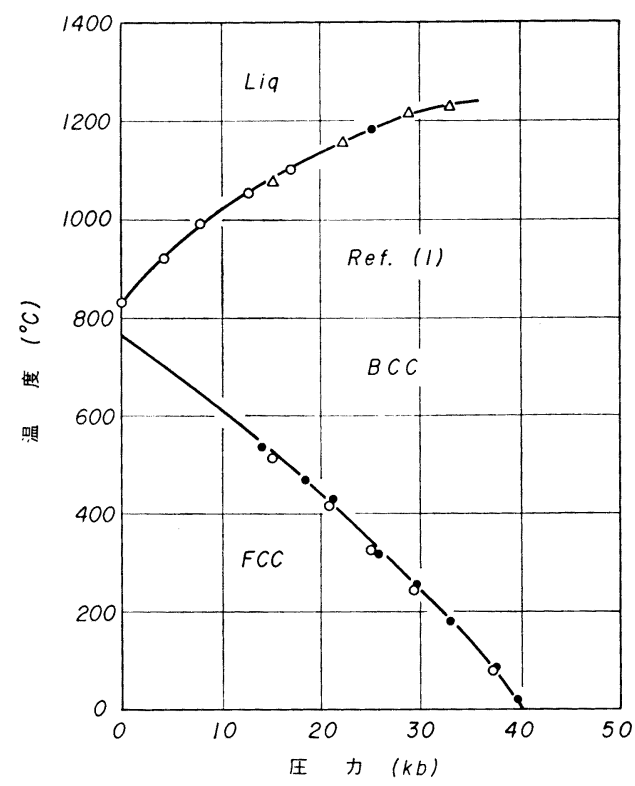

Yb

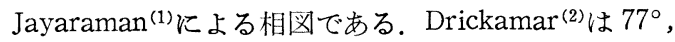
$290^{\circ} \mathrm{K}$ で $250 \mathrm{~kb}$ までの電気抵抗の測定を行なつている. 〜 $40 \mathrm{~kb}$ の圧力で $77^{\circ}, 290^{\circ} \mathrm{K}$ ともに抵抗に鋭い極大值 を見出している.

(1) A.Jayaraman : Phys. of Solid at High Pressure, ed. by C. T. Tomizuka and R. M. Emrick, Academic Press.

(2) H. G. Drickamar : Solid State Physics, vol. 17, ed. by F.Seitz and D.Turbull.

(3) H.T.Hall and L.Merill : Inorg. Chem., 2 (1963), 618 .

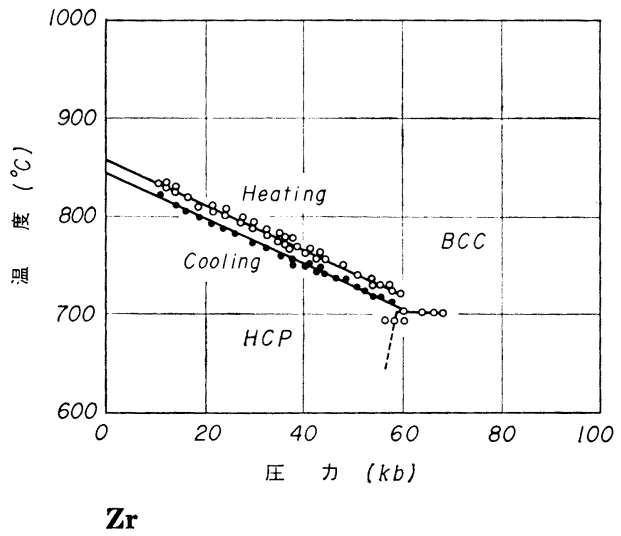

$695^{\circ} \mathrm{C}, 58 \mathrm{~kb}$ で電気抵抗に 1 次転移が起こる(1). 図中 の三重点は $60 \mathrm{~kb}, 695^{\circ} \mathrm{C}$ である. 三重点以上の圧と以 下の温度での相は不明.

(1) A. Jayaraman, W. Klement, Jr. and G. C. Kennedy : Phys. Rev., 131 (1963), 644.

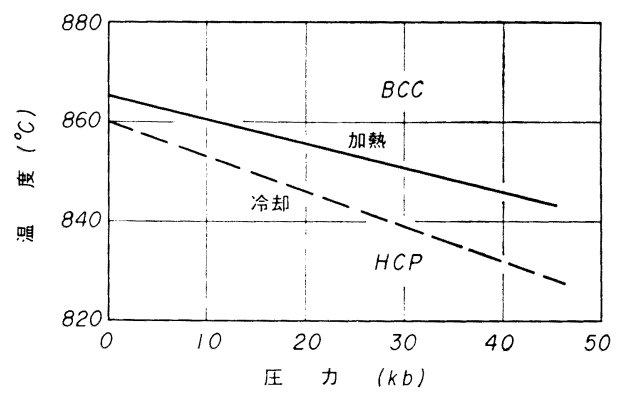

Ti

DTA 法による測定.

(1) A. Jayaraman, W. Klement, Jr. and G. C. Kennedy : Phys. Rev., 131 (1963), 644.

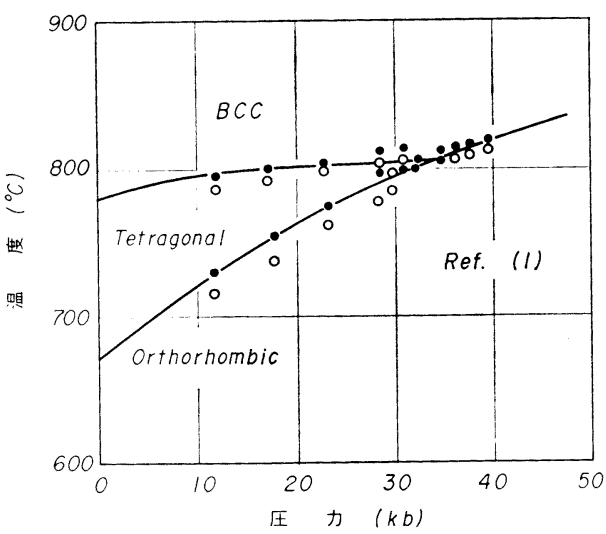

$\mathbf{U}$

DTA 法によつて調べられている(1) $\alpha-\beta-\gamma$ の三重点は $\mathrm{P}<31.5 \mathrm{~kb}, \mathrm{~T}>803^{\circ} \mathrm{C}$ となつている. 浅見, 山田, 高橋 ${ }^{(2)}$ によると, $798^{\circ} \pm 5^{\circ} \mathrm{C}, 29.8 \pm 1.2 \mathrm{~kb}$ である.

(1) W. Klement, Jr., A. Jayaraman and G.C. Kennedy : Phys. Rev., 129 (1963), 1971.

（2）浅見，山田，高橋：金属学会誌，31 (1967)，389.

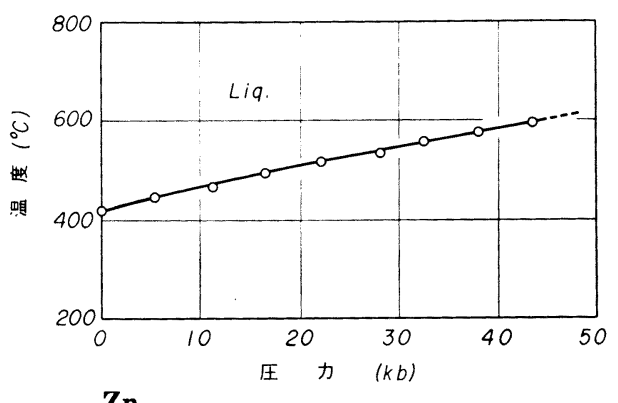

Zn

(1) G.C.Kennedy and R.C.Newton : Solids under Pressure, McGraw-Hill, New York, (1963), p. 163 . 


\section{3. 一成分系の圧カー温度状態図}

単一金属の相転移への圧力と温度の効果を考えてみ る. 最も簡単な場合として, ある金属が 1 気圧力下にお いて $0^{\circ} \mathrm{K}$ と融解点間の温度範囲で単一の安定な変態 $(\alpha$ 相)のみをとるとする， $\alpha$ 相の自由エネルギーは温度と 圧力の関数としてつぎのように書ける.

$$
F^{\alpha}(T, P)=F^{\alpha}(T)+\int_{P_{0}}^{P} V^{\alpha} d P \quad \mathrm{cal} / \mathrm{mol}
$$

$P_{0}$ は 1 気圧, $V$ は体積, $P$ は圧力, $F^{\alpha}(T)$ は 1 気圧下 に技ける自由エネルギーである， $\alpha$ 相がこの金属の最稠 密相ならば, 圧力 $P$ 下の融解曲線 $T_{M}^{\alpha}(P)$ はつぎのよう にして決まる。すなわち, 液相の自由エネルギー $F^{L}(T$, P)を，(1)式と同様にして

$$
F^{L}(T, P)=F^{L}(T)+\int_{F_{0}}^{P} V^{L} d P \quad \mathrm{cal} / \mathrm{mol}
$$

と書きこれと固相の自由エネルギーとの差 $\Delta F^{\alpha \rightarrow L}(T, P)=\Delta F^{\alpha}(T)+\int_{P_{0}}^{P} \Delta V^{\alpha \rightarrow L} d P \mathrm{cal} / \mathrm{mol}(3)$ を求めることから決まる。 $\Delta V^{\alpha \rightarrow L}$ は一般に温度, 圧力 の関数である. 融解点 $T_{M}^{\alpha}$ は圧力の関数で融解曲線 $T_{M}^{\alpha}(P)$ はつぎの条件で定義される.

$$
\Delta F^{\alpha \rightarrow L}\left(T_{M}^{\alpha}, P\right)=0
$$

実際には広範囲の圧力, 温度域での $\Delta F^{\alpha \rightarrow L}(T), \Delta V^{\alpha \rightarrow L}$ という量が知られているわけではないから $T_{M}^{\alpha}(P)$ を正 確に予知することは出来ない相談である。 また，(3) 式 を微分することによつてクラジウスークラペイロンの式

$$
\left(\frac{d T}{d P}\right)_{T_{M}^{a}}^{\alpha \rightarrow L}=\left(\frac{\Delta V}{\Delta S}\right)_{T_{M}^{\alpha}}^{\alpha \rightarrow L}=T_{M}^{\alpha}\left(\frac{\Delta V}{\Delta H}\right)_{T_{M}^{\alpha}}^{\alpha \rightarrow L}
$$

がみちびかれる，この式は融解点の初期勾配を算出する 場合, 融解に際してのエントロピー, 体積などの変化が わかれば用いることが出来る（しかしながら，現在のと ころ正確な $\Delta V$ や $\Delta S$ を与える信頼すべき方法もないよ らである)，以上は金属が融解点まで単一相にある場合 であるが，第 2 の相 $\beta$ をもつ場合はどらか．簡単のため に二つの相 $\alpha$ と $\beta$ はつぎのような条件をみたしている あのとしょ5. (i) $V^{L}>V^{\beta}>V^{\alpha}$. (ii) $\Delta V^{x \rightarrow L}, \Delta V^{\alpha \rightarrow \beta}$ は 温度と圧力によらない.この二つの条件の下で静水圧力 が， $\alpha$ 㧊よび $\beta$ の両変態の安定性にどのような効果を括 よぼすかをみてみる。

(I) $0^{\circ} \mathrm{K} \leq T \leq T_{0}$ での $\alpha$ 相が， $T_{0} \leq T \leq T_{M}^{\beta}$ で $\beta$ 相が 安定な場合 ( $\mathrm{A}$ 図, B図).

転移の潜熱 $\Delta H^{\alpha \rightarrow \beta}\left(T_{0}\right)$, 電解熱 $\Delta H^{\beta \rightarrow L}\left(T^{\beta}{ }_{M}\right), \alpha \rightarrow \beta$, $\beta \rightarrow L$ 転移に伴う体積変化がわかると, クラジウスーク ラペイロンの関係式から, $(d T / d P)^{\alpha \rightarrow \beta},\left(d T_{M} / d P\right)^{\beta \rightarrow L}$, $\left(d T_{M} / d P\right)^{\alpha \rightarrow L}$ が算出でさる。 それから一応温度一圧力 状態図の姿を描くことが可能である. さらに $(\Delta V / \Delta S)$ $\alpha \rightarrow \beta>(\Delta V / \Delta S)^{\beta \rightarrow L}$ とい5条件が成り立つ場合は, B 図 に示されるように三重点が現われることになる.

(II) $0^{\circ} \mathrm{K} \leq T \leq T_{0}$ で $\beta$ 相が， $T_{0} \leq T<T^{\alpha}{ }_{M}$ で $\alpha$ 相が安 定な場合 (C図).

（Ｉ）の場合と同様にして温度-圧力状態図はかけるが, この場合は三重点は現われない.

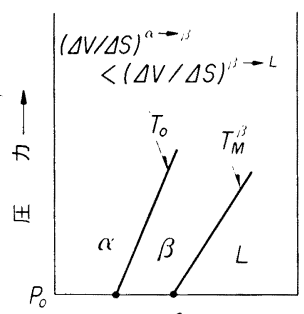

温 度 $\left({ }^{\circ} K\right) \rightarrow$

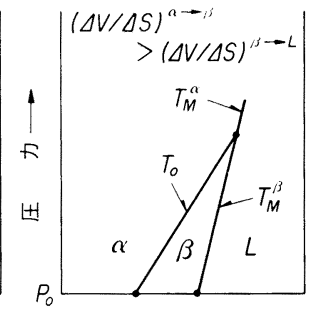

温度 $\left({ }^{\circ} \mathrm{K}\right) \longrightarrow$

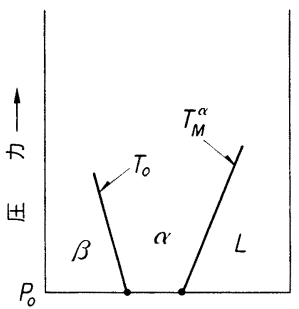

温度 $\left({ }^{\circ} \mathrm{K}\right)$ -
$\left[\begin{array}{l}\Delta V^{\alpha \rightarrow L}>\Delta V^{\beta \rightarrow L}>0 \\ \text { 体 積 変化 } \equiv \text { 一定 }\end{array}\right]\left[\begin{array}{l}\Delta V^{\alpha \rightarrow L}>\Delta V^{\beta \rightarrow L}>0 \\ \text { 体積 変化 } \equiv \text { - 定 }\end{array}\right]\left[\begin{array}{l}\Delta V^{\alpha \rightarrow L}>\Delta V^{\beta \rightarrow L}>0 \\ \text { 体積 変化三一定 }\end{array}\right]$
A図

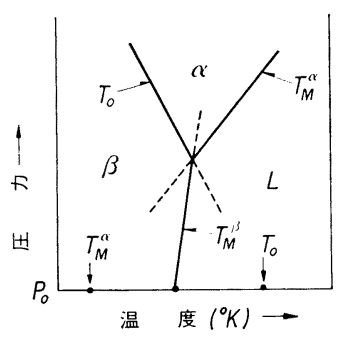

$\Delta S^{\alpha \rightarrow \beta}<0$
$\Delta V^{\alpha \rightarrow L}>\Delta V^{\beta \rightarrow L}>0$

体積変化三一定

D図
B図

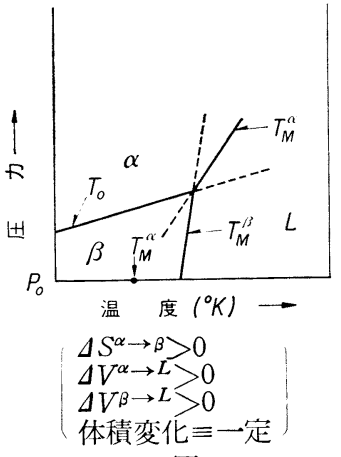

$\mathrm{E}$ 図
(III) 1 気压下で二つの变態が現われ ない場合 ( D図, E図)。

すなわち， $\beta$ 相が 1 気圧下で融点まで 安定である。この場合 $\alpha \rightarrow \beta$ 転移に护け るエントロピー変化の符号に対応してD 図(正)または，E図(負)となる。

\section{4. お わ りに}

本稿で記してきた温度一圧力状態図は, もちろん, 結晶構造の変化を伴う相転移 に関するもののみであつたが，同じく転移に関する圧力 効果としては超電導体の転移点, 強磁性体, 区強磁性体 の磁父転移点, 強誘電体のキューリー点などの圧力変化 が広く研究されている. また, 超電導体や反强磁性体の 場合には,さらに磁場というパラメーターが重要な役割 をはたすようになり, 最近強磁場下の研究の進展に伴い 種々の興味ある成果が報告されている. しかしながら， これらの事柄については本稿の範团をこえると思つたの で割愛することにした。

(つづく) 